\title{
An airborne assessment of atmospheric particulate emissions from the processing of Athabasca oil sands
}

\author{
S. G. Howell ${ }^{1}$, A. D. Clarke ${ }^{1,2}$, S. Freitag ${ }^{2}$, C. S. McNaughton ${ }^{1, *}$, V. Kapustin ${ }^{1}$, V. Brekovskikh ${ }^{1}$, J.-L. Jimenez ${ }^{3}$, and \\ M. J. Cubison ${ }^{3, * *}$ \\ ${ }^{1}$ Department of Oceanography, University of Hawaii, Honolulu, Hawaii, USA \\ ${ }^{2}$ Department of Oceanography, University of Hawaii, Honolulu, Hawaii, USA \\ ${ }^{3}$ Cooperative Institute for Research in the Environmental Sciences and Department of Chemistry and Biochemistry, \\ University of Colorado, Boulder, Colorado, USA \\ *now at: Golder Associates Ltd., Saskatoon, Saskatchewan, Canada \\ ** now at: Tofwerk AG, Thun, Switzerland
}

Correspondence to: S. G. Howell (sghowell@ hawaii.edu)

Received: 31 July 2013 - Published in Atmos. Chem. Phys. Discuss.: 15 August 2013

Revised: 1 February 2014 - Accepted: 5 March 2014 - Published: 23 May 2014

\begin{abstract}
During the Arctic Research of the Composition of the Troposphere from Aircraft and Satellites (ARCTAS) campaign, two NASA research aircraft, a DC-8 and a P$3 \mathrm{~B}$, were outfitted with extensive trace gas (the DC-8) and aerosol (both aircraft) instrumentation. Each aircraft spent about a half hour sampling air around the oil sands mining and upgrading facilities near Ft. McMurray, Alberta, Canada. The DC- 8 circled the area, while the P-3B flew directly over the upgrading plants, sampling close to the exhaust stacks, then headed downwind to monitor the aerosol as it aged. At short range, the plume from the oil sands is a complex mosaic of freshly nucleated ultrafine particles from a $\mathrm{SO}_{2}-$ and $\mathrm{NO}_{2}$-rich plume, soot and possibly fly ash from industrial processes, and dust from dirt roads and mining operations. Shortly downwind, organic aerosol appears in quantities that rival $\mathrm{SO}_{4}$, either as volatile organic vapors condense or as they react with the $\mathrm{H}_{2} \mathrm{SO}_{4}$. The DC-8 pattern allowed us to integrate total flux from the oil sands facilities within about a factor of 2 uncertainty that spanned values consistent with 2008 estimates from reported $\mathrm{SO}_{2}$ and $\mathrm{NO}_{2}$ emissions, though there is no reason to expect one flyby to represent average conditions. In contrast, $\mathrm{CO}$ fluxes exceeded reported regional emissions, due either to variability in production or sources missing from the emissions inventory. The conversion rate of $\mathrm{SO}_{2}$ to aerosol $\mathrm{SO}_{4}$ of $\sim 6 \%$ per hour is consistent with earlier reports, though $\mathrm{OH}$ concentrations are insufficient to accomplish this. Other oxidation pathways must
\end{abstract}

be active. Altogether, organic aerosol and black carbon emissions from the oil sands operations are small compared with annual forest fire emissions in Canada. The oil sands do contribute significant sulfate and exceed fire production of $\mathrm{SO}_{2}$ by an order of magnitude.

\section{Introduction}

Canada's oil sand deposits represent $30 \%$ of total world oil reserves (Alboudwarej et al., 2006) and are estimated at about 180 billion barrels. Most of these resources are in Alberta near the Athabasca River. However, the bitumen contained within the sand is extremely viscous, requiring heat or solvents to extract from the sand. The surface mining operators (e.g., Syncrude Canada, Suncor Energy, Albian Sands Energy) extract the bitumen using a hot water process. About $80 \%$ of the deposits are not recoverable by surface mining and require in situ recovery using steam injection. Before the bitumen can be sent through pipelines and refined, it must be upgraded, a combination of processes that consume natural gas and produce synthetic crude oil and $\mathrm{CO}_{2}$.

There are many sources of aerosols and aerosol precursors in the oil sand extraction and upgrading processes. The bitumen itself releases $\mathrm{SO}_{2}, \mathrm{H}_{2} \mathrm{~S}$ and light hydrocarbons as well as $\mathrm{CO}_{2}$ and $\mathrm{CO}$ on heating (Strausz et al., 1977). Surface mining releases dust directly and road dust and soot are 
produced by trucks. Since the Athabasca bitumen contains approximately $5 \%$ sulfur and $0.5 \%$ nitrogen, the upgrading process can release large quantities of these as $\mathrm{SO}_{2}$ and $\mathrm{NO}_{2}$ as well as soot. The $\mathrm{SO}_{2}$ forms sulfate aerosol at up to $6 \%$ per hour (Cheng et al., 1987). Fly ash has been documented from a coke-burning power plant associated with the upgraders (Barrie, 1980).

Development of the oil sands began with the Great Canadian Oil Sands Company in 1967 but started expanding rapidly around 2000 . As production has increased, the industry has invested heavily in emissions abatement equipment on existing facilities and state-of-the-art low-emission technologies for new facilities in order to ensure regional air quality stays within regulated limits. Oil sands operators are also required to report emissions to the Environment Canada's National Pollutant Release Inventory (http: //www.ec.gc.ca/inrp-npri/) and fund air quality monitoring in the region. As part of their response to environmental issues, the oil sands operators have provided capital and ongoing support for the Wood Buffalo Environmental Association (WBEA), which is a collaboration of communities, environmental groups, industry, government and aboriginal stakeholders. WBEA operates an environmental monitoring program that measures the ambient air quality at about 15 stations throughout the area and continuously monitors environmental effects of air emissions through the Terrestrial Environmental Effects Monitoring Program, which addresses issues such as soil acidification, trace metals in foods harvested by aboriginal communities, and vegetation stress. Data from many of these sites can be accessed directly through the WBEA website (http://www.wbea.org/).

One of the unusual features of the oil sands facilities is their location in an area lacking large populations and other industrial facilities. This makes the emissions more obvious against a relatively clean background. Hence, the oil sands emissions can be discerned in global satellite maps of $\mathrm{NO}_{2}$ and $\mathrm{SO}_{2}$ (McLinden et al., 2012) even though total emissions are smaller than many urban regions. This input of pollutants into a nearly pristine area has been of concern since development began in the area. Studies of aerosol formation (Cheng et al., 1987), deposition (Barrie, 1980; Proemse et al., 2012b) and composition (Proemse et al., 2012a) have been ongoing as have air quality modeling efforts (Davies, 2012).

Despite this emphasis on measuring oil sands emissions, there had been no recent evaluations of them using an extensive airborne instrumentation suite until the summer of 2008, when the NASA DC-8 and P-3B research aircraft were deployed at the Canadian Forces Base Cold Lake in Alberta, Canada. The main focus of the project was to study smoke plumes from the forest fires that occur every year in northern Canada (Jacob et al., 2010), but the two planes detoured one day to measure aerosol and trace gas emissions from the facilities near Ft. McMurray.

The gas-phase data revealed two different types of plumes (Simpson et al., 2010). One was a broad plume that consisted

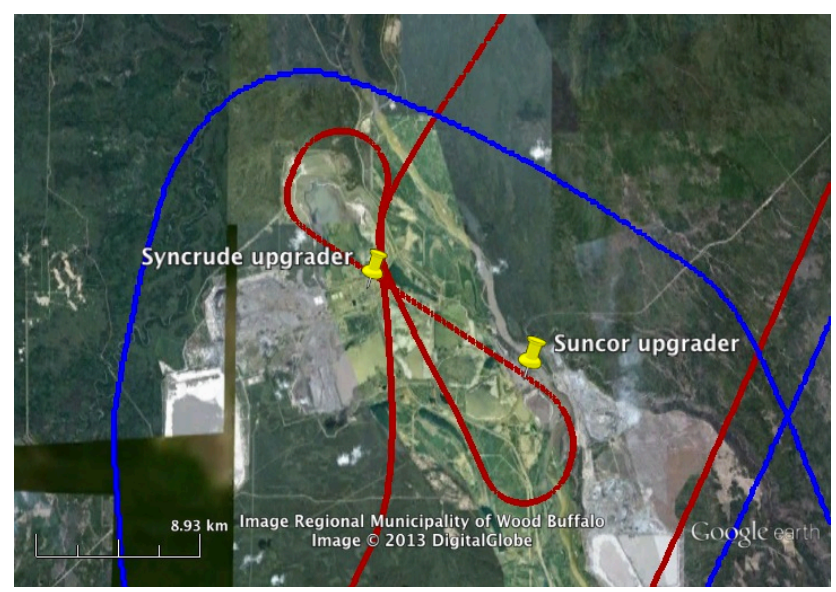

Figure 1. Imagery of the oil sands region from 29 June and flight tracks from 10 July. The DC- 8 track is blue; the P3B red. The two planes entered the area from the north along the parallel tracks to the right. The DC-8 then looped counterclockwise around the facilities at about $350 \mathrm{ma}$ a.g.1; 90 min later the P-3B approached from the south and flew the figure 8 shown, penetrating the Syncrude facility plume three times, twice at about $250 \mathrm{~m}$ a.g.l. and once at $600 \mathrm{~m}$. The Suncor upgrader plume was sampled once, at $250 \mathrm{~m}$.

primarily of light hydrocarbons, presumed to be either from the bitumen or the solvents used to mobilize it. The other was a more typically industrial plume with high concentrations of $\mathrm{NO}_{2}$ and $\mathrm{SO}_{2}$ together with $\mathrm{CO}, \mathrm{CO}_{2}$, and a variety of alkanes, solvents, and halocarbons. The work reported here extends that analysis to include aerosol emissions.

\section{Experimental}

The flights around the Ft. McMurray oil sands upgrading facilities took place on 10 July 2008 . The DC-8 and P-3B took the opportunity to do a joint flight over the oil sands to perform an instrument intercomparison and a brief evaluation of the aerosol and gas emissions from the facilities there (Fig. 1). The DC-8 flew a loop around the facilities at about $350 \mathrm{~m}$ above ground level (a.g.l.), passing through the entire plume and providing upwind samples for contrast. The P-3B flew a figure-8-shaped pattern, passing through visible plumes from the tallest stacks in the facilities (Fig. 2). The Syncrude plume was sampled twice at about $240 \mathrm{~m}$ a.g.l. and once at $625 \mathrm{~m}$, while the Suncor plume was sample once, at about $250 \mathrm{~m}$. After the third Syncrude plume penetration, the $\mathrm{P}-3 \mathrm{~B}$ turned downwind and followed the evolving plume.

In addition to the July 10 flights, there were 3 plume penetrations on other ARCTAS (Arctic Research of the Composition of the Troposphere from Aircraft and Satellites) flights (Fig. 3). The P3-B descended into the mixed layer during transits from fire plume studies on 28 and 29 June, while the DC- 8 flew a low pass early on 28 June looking for a fire 


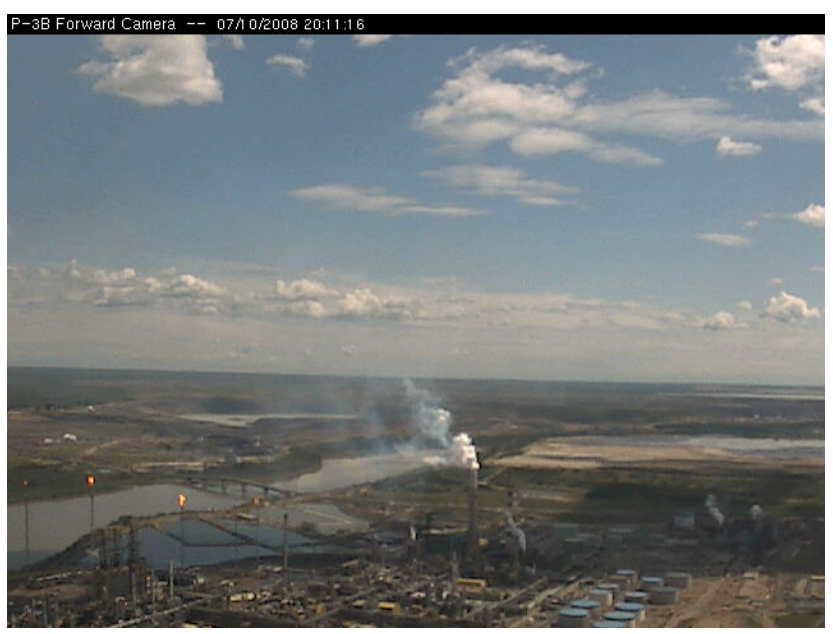

Figure 2. The Suncor facility about $12 \mathrm{~s}$ before the P-3B encountered the white/gray plume. Stacks emitting darker plumes are visible to the left. The Athabasca River, settling ponds, and mined areas are visible in the background. The image is a still from a windshieldmounted video camera

plume from the previous day and coincidentally met the oil sands plume.

\subsection{Instrumentation}

The two aircraft had complementary payloads. The DC-8 was outfitted with an extensive suite of gas-phase and aerosol instruments. The P-3B had similar aerosol measurements and several radiation propagation measurements, but no gasphase capability beyond $\mathrm{CO}$ and $\mathrm{O}_{3}$. Both aircraft used the aerosol inlet characterized by McNaughton et al. (2007), who found that it efficiently conveyed dust particles of up to a few microns in diameter. Additional information can be found at http://www.espo.nasa.gov/arctas/airborne_inst.php. Rather than describing the entire set of measurements, a short description of the most relevant ones is included here.

Number concentration measurements were almost identical on both aircraft. The concentration of particles $>3 \mathrm{~nm}$ were measured with TSI model $3025 \mathrm{~A}$ ultrafine condensation nuclei (UCN) counters. Particles $\gtrsim 10 \mathrm{~nm}$ were measured with a pair of TSI model 3010 condensation nuclei $(\mathrm{CN})$ counters operated with a temperature difference of $22^{\circ} \mathrm{C}$ between saturator and condenser. One (called CNcold henceforth) had no additional heat applied to the inlet, while the other had an inlet tube heated to $350^{\circ} \mathrm{C}$ for about $0.1 \mathrm{~s}$ to remove most volatile material (CNhot). CNhot is typically associated with combustion, as flames produce nonvolatile black carbon (BC) and organic material, though dust, sea salt, and volatile particles too large to evaporate entirely can also contribute (Clarke, 1991). Differences between UCN and $\mathrm{CNcold}$ show particles in the 3 to $10 \mathrm{~nm}$ range indicative of recent new particle formation (nucleation). $\mathrm{UCN}$ and $\mathrm{CN}$ cold suffered from saturation of the counters-concentrations

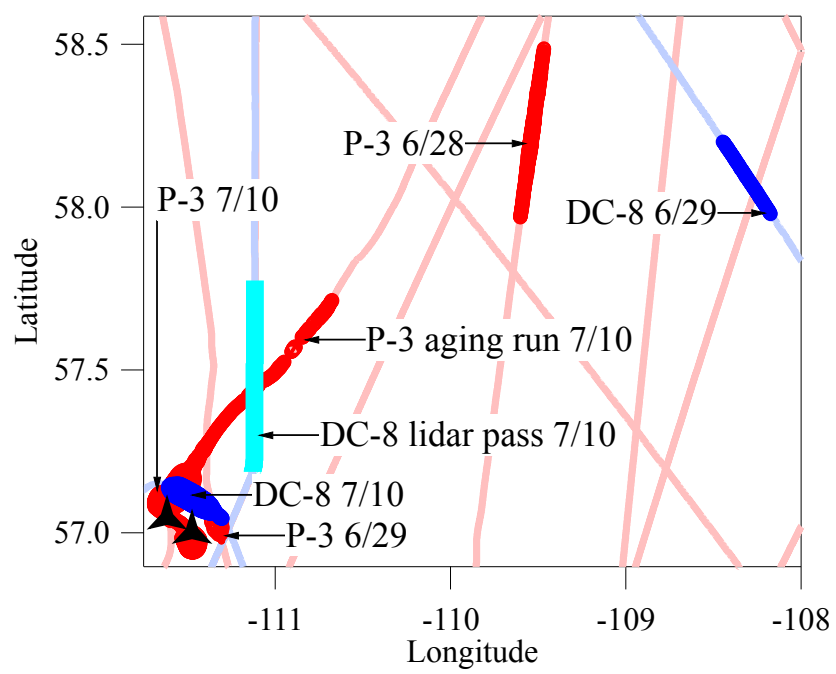

Figure 3. Flight tracks during ARCTAS that passed near the oil sands facilities. Red traces are the P-3B; DC- 8 tracks are blue. Emphasized sections are where the aircraft intercepted the plume.

so high that multiple particles were in the sensing volume simultaneously and were not counted properly. The counters used for CNcold and CNhot do not compensate for coincident particles, which becomes a problem at $>10 \times 10^{3} \mathrm{~cm}^{-3}$. A correction algorithm was applied (Baron and Willeke, 2001), but the algorithm fails above about $35 \times 10^{3} \mathrm{~cm}^{-3}$, when particles are in the sampling volume $\geq 50 \%$ of the time. The UCN counter automatically compensates for coincident particles, but saturates at $100 \times 10^{3} \mathrm{~cm}^{-3}$.

Aerosol size distribution measurements differed modestly between the platforms. Both used scanning mobility particle sizers (SMPSs, using TSI long DMA (differential mobility analyzer) model $3081 \mathrm{~s}$ ) for particles from $\sim 10$ to $400 \mathrm{~nm}$, optical particle counters (OPCs) for rapid measurement of the accumulation mode $(0.2$ to $1 \mu \mathrm{m})$, and aerodynamic particle sizers (APS, TSI model 3321) to measure aerodynamic particle diameters between $\sim 0.8 \mu \mathrm{m}<D_{\mathrm{ae}}<$ $10 \mu \mathrm{m}$. The DC-8 used a DMT UHSAS (ultra-high sensitivity aerosol spectrometer) OPC, which resolves smaller particles $(0.055$ to $1 \mu \mathrm{m})$ at a higher rate $(1 \mathrm{~Hz})$ than the modified LAS$\mathrm{X}$ OPC on the P3-B $(0.2$ to $3 \mu \mathrm{m}, 0.33 \mathrm{~Hz})$, though the latter had a set of heated inlets that could explore volatility at 150 , 300 , and $400^{\circ} \mathrm{C}$ (residence times $>1 \mathrm{~s}$ ). The P-3B also had an SMPS with a TSI radial DMA with unheated and $300^{\circ} \mathrm{C}$, $0.1 \mathrm{~s}$ inlets that spanned 10 to $200 \mathrm{~nm}$. The two SMPSs on the P-3B used grab samplers (Clarke et al., 1998) to ensure that size distributions were from a single sample of air, not affected by changes in airmass over the scanning period.

Aerosol composition measurements were similar on the two aircraft. Nonrefractory submicron composition was measured with Aerodyne high-resolution time-of-flight aerosol mass spectrometers (AMSs) with vaporizers at $600^{\circ} \mathrm{C}$ (DeCarlo et al., 2006). The P-3B AMS ran on an approximately 
$40 \%$ duty cycle, blanking $2 \mathrm{~s}$, sampling for $2 \mathrm{~s}$, and taking about a second to prepare for the next cycle. The DC- 8 ran in so-called "fast mode" (Kimmel et al., 2011) with a duty cycle of about $75 \%$. Both instruments used pressure-controlled inlets (Bahreini et al., 2008) to stabilize conditions at the aerodynamic lens. The P-3B instrument was controlled at $600 \mathrm{hPa}$ during the periods reported here, while the DC- 8 was at $200 \mathrm{hPa}$. At $780 \mathrm{hPa}$, Liu et al. (2007) found that the AMS effectively sampled particles from roughly 60 to $700 \mathrm{~nm}$ vacuum aerodynamic diameter $(50 \%$ sampling efficiency cutoffs). Note that vacuum aerodynamic diameter $\left(D_{\mathrm{VA}}\right)$ is inversely proportional to density, so cuts are smaller for typical atmospheric particles, probably 30 or $45 \mathrm{~nm}$ at the low end to roughly 400 for the P3-B (the DC-8 50\% size cut for large particles was measured at about $1 \mu \mathrm{m} D_{\mathrm{VA}}$, or about $700 \mathrm{~nm}$ actual diameter.)

The measurements used here are bulk (not size-resolved) $\mathrm{SO}_{4}, \mathrm{NO}_{3}, \mathrm{NH}_{4}$ and nonrefractory organic aerosol (OA) mass concentrations extracted using the publicly available Squirrel software (Allan et al., 2003, 2004; DeCarlo et al., 2006) and the collection efficiencies described in Middlebrook et al. (2012). The AMS has difficulty separating organic from inorganic sulfates, nitrates, and ammonium (Farmer et al., 2010); we refer to those radicals without charges (e.g., $\mathrm{SO}_{4}$ as opposed to $\mathrm{SO}_{4}^{=}$) as a reminder that we may not be measuring only inorganic ions.

BC was measured with DMT single-particle soot photometers (SP2s; Schwarz et al., 2006; Stephens et al., 2003). Unfortunately, the DC-8 SP2 was not operational on 10 July. Particle sizes that can be detected by SP2s depend on details of instrument setup, but generally particles below $100 \mathrm{~nm}$ are not always detected and $80 \mathrm{~nm}$ particles are missed entirely, as their incandescence is too faint to be detected. For typical soot plumes, SP2s detect nearly the entire mass of BC, but can miss a significant fraction of the $\mathrm{BC}$ number concentration. The DC-8 had additional aerosol composition measurements, but at rates too slow to capture the oil sands plume.

The aerosol optics packages on both aircraft included TSI model 3563 nephelometers (Anderson et al., 1996) measuring light scattering $B_{\mathrm{sp}}$ at 450,550 , and $700 \mathrm{~nm}$ and Radiance Research particle soot absorption photometers (PSAPs) obtaining light absorption $B_{\text {ap }}$ at 470,530, and $660 \mathrm{~nm}$. Nephelometer data were corrected for truncation errors using the procedures from Anderson and Ogren (1998). PSAP corrections were performed according to Virkkula et al. (2005) and Virkkula (2010).

As mentioned above, the DC- 8 had an extensive set of trace gas measurements. Of particular interest here are $\mathrm{CO}$, $\mathrm{SO}_{2}, \mathrm{NO}_{2}, \mathrm{NO}_{\mathrm{x}}$, and a suite of hydrocarbons and halocarbons collected in stainless steel chambers and measured with gas chromatography at UC Irvine. More extensive gas-phase data are reported in Simpson et al. (2010).

The DC-8 was equipped with a differential absorption lidar (DIAL; Browell et al., 1998; Dupont et al., 2012) which provides a 2-D curtain of backscatter data above and below the aircraft at 591 and $1064 \mathrm{~nm}$. Data are presented here as attenuated aerosol backscatter ratio, defined as one less than the ratio of lidar return $L$ to that calculated for an atmosphere lacking aerosol $L_{\mathrm{m}}$.

$R_{\mathrm{ba}} \equiv \frac{L}{L_{\mathrm{m}}}-1=\frac{\left[\beta_{\mathrm{p}}+\beta_{\mathrm{m}}\right]}{\beta_{\mathrm{m}}}\left(1-\varepsilon_{\mathrm{p}}\right)^{2}-1 \approx \frac{\beta_{\mathrm{p}}}{\beta_{\mathrm{m}}}$ if $\varepsilon_{\mathrm{p}} \ll 1$,

where $\beta_{\mathrm{p}}$ and $\beta_{\mathrm{m}}$ are backscattering due to particles and molecules (air), respectively, and $\varepsilon_{\mathrm{p}}$ is extinction along the beam due to particles. For the qualitative analysis here, this approximation is sufficient, but note that $R_{\mathrm{ba}}$ is an underestimate of the actual backscatter ratio when $\varepsilon_{\mathrm{p}}$ is significant, which often occurs when the DIAL penetrates thin clouds.

\section{Results and discussion}

The 10 July 2008 flights provide the bulk of our data. It was a clear day with scattered low clouds and some higher clouds in the distance (Fig. 2). Surface winds below $1 \mathrm{~km}$ were from the SSW at 3 to $7 \mathrm{~m} \mathrm{~s}^{-1}$ (near the climatological mean) but increased with altitude to $15 \mathrm{~m} \mathrm{~s}^{-1}$ at $1 \mathrm{~km}$ and about $20 \mathrm{~m} \mathrm{~s}^{-1}$ at $3.5 \mathrm{~km}$. Above $1 \mathrm{~km}$ winds transitioned to about $215 \pm 15^{\circ}$. Convective activity and clouds were present in the area, but no precipitation was evident. Some clouds interacted with emission plumes, apparently mixing them to higher altitudes.

\subsection{Near-field characterization}

The closest plume penetrations by the P-3B were too quick for the PSAPs and size distributions, but the rapid-response measurements showed the plumes clearly (Fig. 4). $\mathrm{SO}_{4}$ and $\mathrm{CO}$ were found almost exclusively in the visible plumes from the tallest stacks. In contrast BC and OA appear to be produced in other locations as well, probably including the flaring stacks visible at the lower left in Fig. 2. Scattering and $\mathrm{CN}$ show both influences, dominated by the tall stacks but with other sources evident. This shows that the plumes from the upgrading facilities are spatially heterogeneous, with a variety of plume compositions.

The behavior of organic aerosol after the last penetration is striking. Little OA was emitted directly - there were only small fluctuations during the close passes - but OA concentrations jumped to almost equal $\mathrm{SO}_{4}$ as soon as the plane turned downwind at 20:15 (this and all times mentioned are UTC, $6 \mathrm{~h}$ later than local daylight savings time). The roughly $1: 1$ ratio between $\mathrm{OA}$ and $\mathrm{SO}_{4}$ persisted for the rest of the leg.(Fig. 4). It is conceivable but unlikely that OA was present at diameters too small for the AMS to detect; that would require a huge population of particles growing more slowly than the freshly nucleated sulfates. The origin of the organic matter is not clear; the high correlation with $\mathrm{SO}_{4}$ suggests a common source, but it is conceivable that organic material was mixing up into the $\mathrm{SO}_{4}$ plume from lower-altitude 


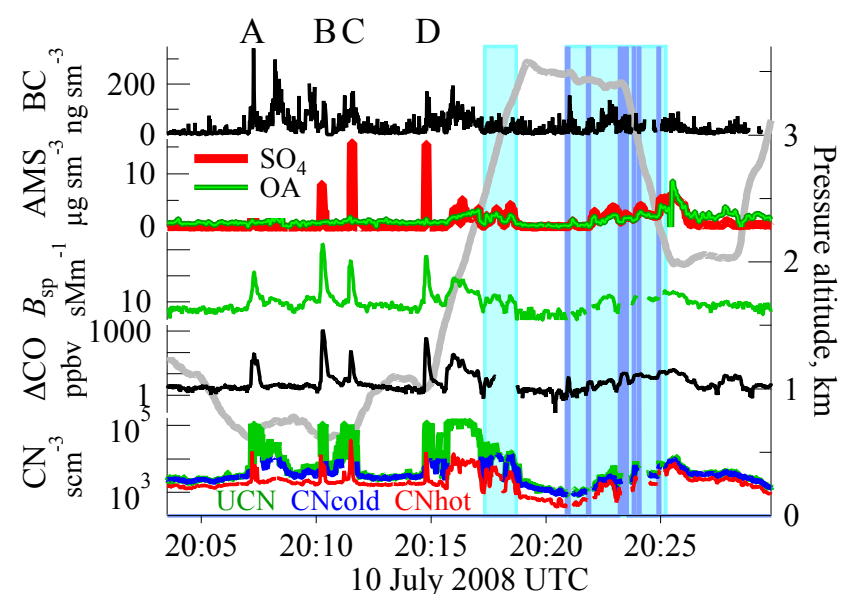

Figure 4. Data along the P-3B flight track shown in Fig. 1. Syncrude upgrader plume penetrations occurred at points A, B, and D, while the Suncor plume was encountered at point C. Light-blue regions indicate periods when the plane was among clouds; darker blue shows cloud penetrations. Note that the UCN and CN saturate at $1 \times 10^{5} \mathrm{~cm}^{-3}$ and $3 \times 10^{4} \mathrm{~cm}^{-3}$, respectively; actual values are higher than shown. The AMS was on a 5 s cycle, blanking half the time, so it may have missed peak concentrations. $\mathrm{CN}, \mathrm{CO}$, and scattering $\left(B_{\mathrm{sp}}\right)$ are on log scales; $\mathrm{CO}$ has the minimum concentration of 93.6 subtracted. The light-blue background shows periods among clouds; darker blue indicates cloud penetrations. Light scattering, $B_{\text {sp }}$, is at $550 \mathrm{~nm}$.

sources. Perhaps the extensive vapor-phase measurements of the DC-8 could distinguish between those possibilities, but the P-3B payload lacked that capability. It is also not immediately apparent whether the organic aerosol was simply condensation of semivolatile vapors as the plume cooled with altitude (and is thus primary OA) or whether photochemical reactions could have produced secondary organic material in the short period since emission. Elemental analysis of the AMS mass spectra revealed median $\mathrm{O}: \mathrm{C}=0.26$ and $\mathrm{H}: \mathrm{C}=1.5$, characteristic of fresh mixed primary and secondary OA (Aiken et al., 2008), which is also consistent with the mass spectral pattern observed by $\mathrm{Ng}$ et al. (2011).

It is likely that reactions with $\mathrm{H}_{2} \mathrm{SO}_{4}$ are responsible for much of the OA. The high acidity of the plume could catalyze polymerization of aldehydes (Jang et al., 2002), react with alkenes such as isoprene (Surratt et al., 2007) or react with alcohols such as 2-methyl-3-buten-2-ol (Zhang et al., 2012). While much of the organic vapor in the oil sands plume was aliphatic and thus unreactive, alcohols and alkenes such as isoprene, $\alpha$-pinene, and $\beta$-pinene were enhanced (Simpson et al., 2010). Biogenic vapors from the surrounding forest may also have contributed.

As part of the downwind leg, the P-3B explored the vertical structure of the plume by ascending through the mixed layer and the cloud layer, then profiling back down to the mixed layer. Cloud base was about $2.2 \mathrm{~km}$. During the ascent, clouds were avoided, but pulses of aerosol were clearly as-

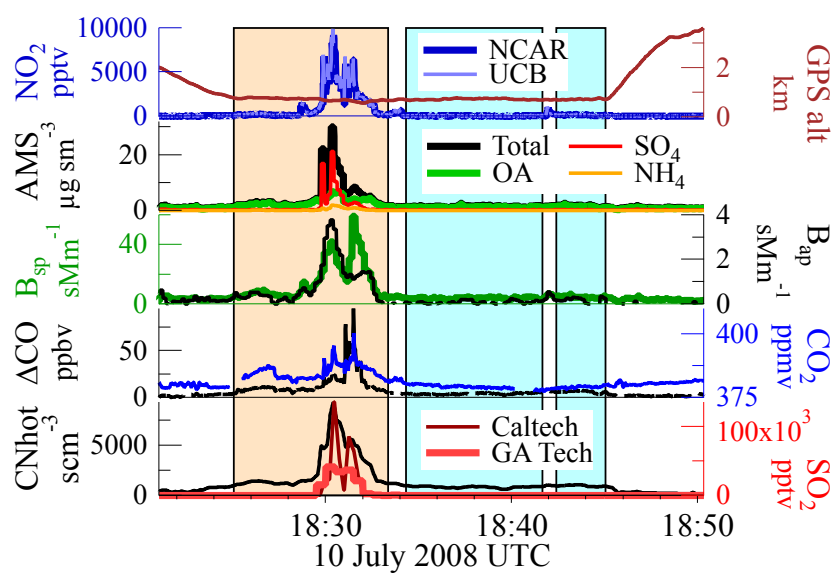

Figure 5. The oil sands plume as seen by in situ instruments on the DC-8. The light-blue region was when the plane was upwind of the facilities, while light brown indicates the plume. The plane flew parallel to the wind at 18:34, so no flux could be calculated. The gap at 18:43 is there because of the $\mathrm{NO}_{2}$ and $B_{\text {ap }}$ spikes, which appear consistent with diesel truck traffic. The period from 18:25 to $18: 28$ was downwind of both mining operations and the town of Ft. McMurray. Scattering, $B_{\mathrm{sp}}$, is at $550 \mathrm{~nm}$, while absorption, $B_{\mathrm{ap}}$, is at $532 \mathrm{~nm}$.

sociated with close approaches. Similar pulses were present in and between clouds during the descent (blue regions in Fig. 4). It is not clear how much of the sulfate in and around clouds was due to the well-known aqueous-phase reaction of $\mathrm{SO}_{2}$ with $\mathrm{H}_{2} \mathrm{O}_{2}$ (Penkett et al., 1979). In this case the reaction is limited by the roughly 500 pptv concentration of $\mathrm{H}_{2} \mathrm{O}_{2}$ seen by the DC- 8 , which could produce as much as $2 \mu \mathrm{g} \mathrm{m}^{-3}$ $\mathrm{SO}_{4}$. Reaction of $\mathrm{SO}_{2}$ with $\mathrm{NO}_{2}$ in cloud droplets could be a significant source of $\mathrm{SO}_{4}$ (Littlejohn et al., 1993; Sarwar et al., 2013), though this is a $\mathrm{pH}$-dependent reaction that may be limited by available $\mathrm{NH}_{3}$ (which was not measured).

Figure 5 shows a similar data set from the DC-8. At the $10 \mathrm{~km}$ distance of this sampling, the plume is more mixed, but some of the same features are visible. There is a doublehump structure to many of the species. Given the winds and flight direction, the first peak is from Suncor and the second from Syncrude. As with the $\mathrm{P}-3 \mathrm{~B}, \mathrm{SO}_{4}$ was found in a narrower region, indicating a couple of discrete sources. $\mathrm{SO}_{2}$ behaved similarly, while other species were more widely spread out. $\mathrm{NH}_{4}$ was also higher in the plume, but not sufficiently to neutralize the $\mathrm{SO}_{4} . \mathrm{NH}_{4}: \mathrm{SO}_{4}$ dropped from $\sim 1.5$ in background air to 0.5 in the heart of the plume, indicating that $\mathrm{NH}_{3}$ was limited and the plume was acidic. Before the main plumes, from 18:25 to 18:28, scattering, absorption, $\mathrm{OA}, \mathrm{CO}$, $\mathrm{CO}_{2}$, and $\mathrm{CNhot}$ were all moderately enhanced, due either to mining or the city of Ft. McMurray. In contrast, $\mathrm{NO}_{2}$ was quite low during that period.

Size distributions in the plume seen by the DC- 8 are complex (Fig. 6). The APS (top panel) shows modes at $3 \mu \mathrm{m}$ at $18: 30$ and $18: 32$. That is typical for dust made mechanically 


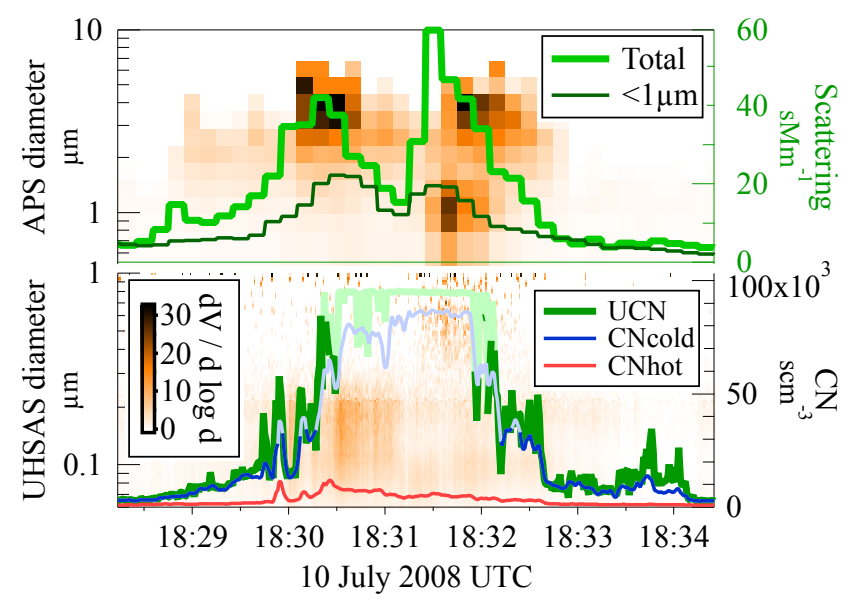

Figure 6. Aerosol volume superimposed on some of the data from Fig. 5. The upper panel shows total and submicron light scattering at $550 \mathrm{~nm}$ and the coarse aerosol volume distributions measured by the APS. The lower panel shows UCN, CNcold and CNhot over sub- $\mu \mathrm{m}$ volume distribution from the UHSAS. Pale traces show UCN and CNcold saturation; true values are higher.

and is likely to be road dust, from mining, or from crushing or mixing gravel. The mode peaking at $1 \mu \mathrm{m}$ around 18:31:40 is more unusual - too small for road dust (e.g., Singh et al., 2002) or natural dust, even after long transport (e.g., Mahowald et al., 2014; Maring et al., 2003), and much larger than the typical accumulation mode of 0.1 to $0.3 \mu \mathrm{m}$ from gas-to-particle conversion. The latter is also seen in the UHSAS data at that time (bottom panel) at about $0.6 \mu \mathrm{m}$. Since aerodynamic diameter as measured by the APS is related to geometric diameter by approximately the square root of density, this implies a particle density of at least $2.8 \mathrm{~g} \mathrm{~cm}^{-3}$ (or higher if the refractive index caused the UHSAS to oversize the particles). This could be fly ash from petroleum coke combustion, as was reported by Barrie (1980). Total and submicrometer light scattering is also plotted in the top panel. It is no surprise that coarse-mode scattering is high during the dust events. However, maximum scattering occurred with the suspected fly ash, since $1 \mu \mathrm{m}$ particles are near the peak of mass scattering efficiency.

Figure 6 also reveals that near 18:30:30 the 0.1 to $0.2 \mu \mathrm{m}$ accumulation mode caused $80 \%$ of the scattering. This is coincident with the $\mathrm{SO}_{4}$ and OA peaks from the AMS (Fig. 5). These sizes are very effective as cloud condensation nuclei $(\mathrm{CCN})$ in boundary layer (BL) clouds. CNhot, which typically consists mainly of $\mathrm{BC}$ and refractory organics (Clarke et al., 2007) is enhanced during the same period but also shows narrow peaks at other times (e.g., near 18:30). This is similar to those seen in the P3B data for stack emissions with high BC (Fig. 4). Consequently, the size distributions indicate different sources or processes embedded in the broad oil sands plume contribute differently to both coarse and fine aerosol.

\subsection{Vertical structure}

Although aircraft have the ability to survey in 3 dimensions, in situ measurements are limited to a 1-D line of observations along the flight track. A lidar curtain is an effective way to add a dimension, and thus context, to aerosol data. However, because aerosol size depends upon water uptake in response to relative humidity that generally varies with altitude (Shinozuka et al., 2011), the backscatter cannot directly quantify emitted dry aerosol mass. The DC-8 lidar had difficulty penetrating clouds in some spots, but did provide an overview of the plume (Fig. 7).

Figure $7 \mathrm{~b}$ relates the lidar curtain and location of the plume to winds and geography. The wind vectors do not line up precisely with the 18:03 start of the plume or maximum at 18:06 as seen by the lidar, but small changes in wind direction are likely in the few hours it took the plume to reach the lidar track. The backscatter peak between 18:10 and 18:11 is probably due to mining operations (see Fig. 1), but its magnitude is deceptive - the cloud at $4 \mathrm{~km}$ between 18:05 and 18:09 suppresses the lower-altitude backscatter. The continued plume to $18: 13: 30$ is nearly downwind of the city of Ft. McMurray. Aerosol in the main plume appears to be mixed fairly uniformly to about $1450 \mathrm{~m}$, but is drawn higher by convection around 18:05, presumably in a manner similar to that seen by the P-3B among clouds in Fig. 4.

\subsection{Fluxes}

One of the advantages of sampling from a mobile platform is that one can cross the entire plume and integrate a total flux if the vertical structure is known. The flux in the direction of the wind through the vertical projection of the flight track between times $t_{0}$ and $t_{1}$ is

$Q=\int_{t_{0}}^{t_{1}} \int_{0}^{z_{\mathrm{m}}}\left(S-S_{0}\right) v_{\mathrm{w}} v_{\mathrm{a}} \sin \left(\phi_{\mathrm{a}}-\phi_{\mathrm{w}}\right) \mathrm{d} z \mathrm{~d} t$,

where $z_{\mathrm{m}}$ is the top of the boundary layer, $S$ and $S_{0}$ are the plume and background concentrations, $v_{\mathrm{a}}$ and $\phi_{\mathrm{a}}$ are aircraft speed and heading in Earth coordinates, and $v_{\mathrm{w}}$ and $\phi_{\mathrm{w}}$ are the wind speed and direction (White et al., 1976; Ryerson et al., 1998). If we assume winds and concentration are constant with altitude throughout the mixed layer and there is no vertical flux above the mixed layer, then the discrete version of Eq. (2) becomes

$Q=z_{\mathrm{m}} \sum_{t_{0}}^{t_{1}}\left(S-S_{0}\right) v_{\mathrm{w}} v_{\mathrm{a}} \sin \left(\phi_{\mathrm{a}}-\phi_{\mathrm{w}}\right) \Delta t$.

The flux from a source equals that through the flight path curtain if there are no significant sources or sinks along the way.

The DC-8 loop around the two major upgraders is well suited to such a calculation. The upwind part of the loop provides the background concentrations (blue areas of Fig. 5) 

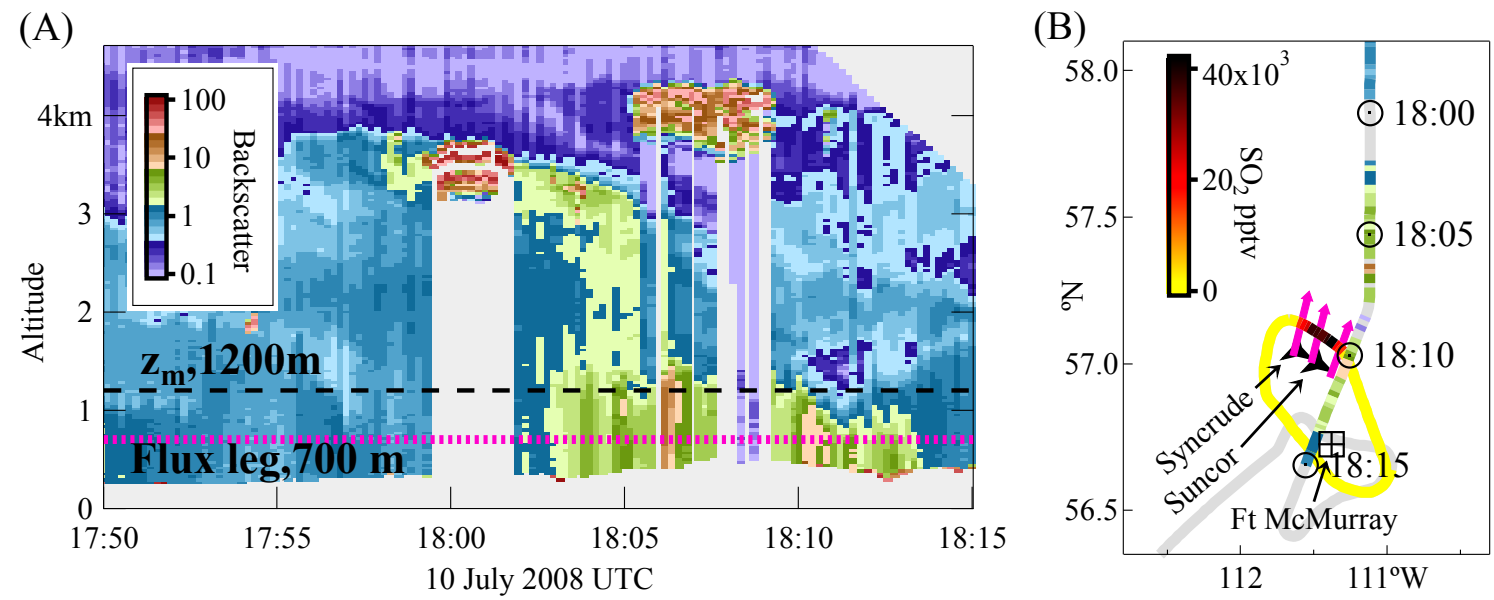

Figure 7. (A) Near-infrared $(1064 \mathrm{~nm})$ lidar curtain as the DC-8 approached the oil sands area. The plane was at 5.5 km until 18:10, when it started descending. Gray areas are the blanking interval around the plane, below ground level, or obscured by cloud. The plume is obvious starting at about 18:03 with a maximum at 18:06. Note that cloud partly obscures the peak, so the aerosol scattering ratio is an underestimate. Around 18:04 some of the plume is clearly exiting the mixed layer, perhaps due to convection associated with the cloud remnant at $3.2 \mathrm{~km}$. The dashed line is the mixed-layer top (from Fig. 8) and the magenta line is at the altitude of the in situ plume penetration. (B) Location of the curtain with respect to sources and the plume as observed in situ. The track from 17:50 to 18:15 is colored with the lidar curtain data from the in situ altitude, while the low-altitude loop is colored by $\mathrm{SO}_{2}$ concentration. Magenta arrows show $2 \mathrm{~h}$ of wind advection as measured by the DC-8.

to subtract from the plume concentrations (brown). The primary difficulty and major source of uncertainty is in establishing the mixed-layer height $z_{\mathrm{m}}$. The DC-8 did no vertical profiles in the plume, so we have no direct measurements of mixed-layer depth then and there. Figure 8 shows vertical profile data from the lidar and in situ instruments. The lidar profiles are near the in situ leg, while the profiles were upwind but closer in time to the plume penetration. The lidar shows a fairly uniform mixed layer topping out at 1000 to $1200 \mathrm{~m}$. In contrast, the potential temperature suggests a very stable boundary layer with very little vertical mixing. Water vapor and $\mathrm{CN}$ concentrations are not uniform, but have minima near $1200 \mathrm{~m}$. That, together with the lidar, makes $1200 \mathrm{~m}$ a reasonable choice for mixed-layer depth. Since the ground level is about $300 \mathrm{~m}$, we use a mixed-layer depth of $900 \mathrm{~m}$, but it could be as small as 700 or as large as $1500 \mathrm{~m}$ (the P3B profile about $100 \mathrm{~min}$ later showed $\mathrm{CO}$ capped at about $1800 \mathrm{~m})$.

Table 1 shows the results of the flux calculations for

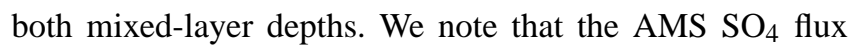
is roughly $5 \%$ of the $\mathrm{SO}_{2}$ flux roughly an hour downwind of the upgraders, consistent with Cheng et al. (1987), who found that $\mathrm{SO}_{2}$ from the upgraders reacted at about $6 \%$ per hour. This conversion rate cannot be explained by reaction with $\mathrm{OH}$ alone. The $\mathrm{OH}$ concentration measured on the DC- 8 was slightly elevated, averaging about $0.11 \mathrm{pptv}$ across the plume except at the $\mathrm{SO}_{2}$ peak, when it dropped to 0.05 pptv. Background concentrations averaged $0.07 \mathrm{pptv}$. At $0.1 \mathrm{pptv} \mathrm{OH}, 286 \mathrm{~K}$, and $92500 \mathrm{~Pa}$ the reaction rate coefficient is $1.06 \times 10^{-12} \mathrm{~cm}^{3}$ molecule ${ }^{-1} \mathrm{~s}^{-1}$ (Blitz et al., 2003), consuming $310 \mathrm{pptv} \mathrm{SO}_{2} \mathrm{~h}^{-1}$, or about $1 \%$ per hour. If $\mathrm{SO}_{2}$ from the stacks is the only source of $\mathrm{SO}_{4}$, reaction with $\mathrm{OH}$ is less than $20 \%$ of the total $\mathrm{SO}_{2} \rightarrow \mathrm{SO}_{4}$ conversion. The rapid reaction of $\mathrm{SO}_{2}$ with $\mathrm{H}_{2} \mathrm{O}_{2}$ in cloud droplets is not relevant here, as the few clouds present were well above the mixed layer (Fig. 7). Aqueous chemistry can occur immediately as the effluent leaves the stacks (Fig. 2 shows apparent liquid water droplets), but we were not equipped to determine how much $\mathrm{H}_{2} \mathrm{O}_{2}$ could diffuse in before the water vapor evaporates.

Since the SP2 was not functioning on the DC-8, we used absorption data from the sub- $\mu$ m PSAP. Particulate mass absorption efficiency (MAE) is usually reported as between 5 and $20 \mathrm{~m}^{2} \mathrm{~g}^{-1} \mathrm{BC}$, depending on the geometry of the soot and its coatings (Fuller et al., 1999). The P-3B had functioning PSAPs and SP2 that day, so MAE immediately adjacent to the upgraders could be determined, as shown in gray in Figure 9. Water vapor fluctuations in the biggest plumes caused large positive and negative artifacts in the PSAP signals that had to be edited out, but BC was primarily found outside those plumes, so the average should be valid. The data are entirely consistent with the MAE of $7.5 \pm 1.2 \mathrm{~m}^{2} \mathrm{~g}^{-1}$ for uncoated soot found by Bond and Bergstrom (2006). However, rapid changes in particle composition as the plume ages are likely to affect MAE, so the P-3B flyby on 29 June is probably more representative of the 10 July DC- 8 data, as both were about $10 \mathrm{~km}$ downwind. As seen in black in Fig. 9, the data, while scattered and a bit sparse, indicate MAE is roughly double that of the 10 July close pass. This amplification is as expected for 


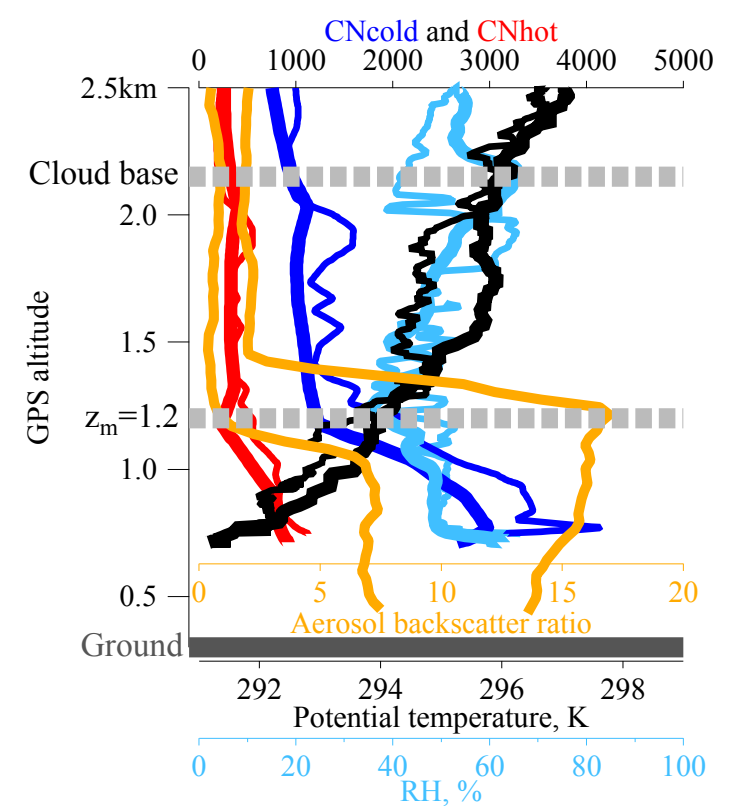

Figure 8. Vertical profile data from the DC- 8 near the oil sands plume. Aerosol backscatter ratios are from 18:06:20 (near the peak of the plume downwind of the sampling loop) and 18:10:20 (near where the lidar curtain crossed the sampling loop). Other data are from the descent into (thin lines) and ascent out of (thick lines) the sampling leg, which occurred upwind of the emissions sources. The choice of mixed layer depth, $z_{\mathrm{m}}$, for the flux calculation was based on the lidar data. Potential temperature indicates a surprisingly stable boundary layer. In contrast, water vapor and RH suggest that the mixed layer extends to near cloud base at 2.0 to $2.2 \mathrm{~km}$.

Table 1. Fluxes calculated from the DC-8 loop around the oil sands facilities on 10 July and the P3-B plume penetration on 28 June. Estimated errors are roughly a factor of 2 for the DC- 8 flyby (Table 2) and higher for the P3-B. The latter column includes a range of values since the plume width is ambiguous. See text and Fig. 10b. "Reported" values are from Environment Canada (2008a) and the Greenhouse Gas Inventory (for $\mathrm{CO}_{2}$ ), reporting year 2008. All sources within the DC-8 loop are included, though the Syncrude and Suncor upgraders are by far the largest.

\begin{tabular}{lrrr}
\hline & \multicolumn{2}{c}{ Flux, g s } & \\
Species & DC-8, $10 \mathrm{~km}$ & $\mathrm{P} 3-\mathrm{B}, 180 \mathrm{~km}$ & Reported \\
\hline $\mathrm{NO}_{2}(\mathrm{NCAR})$ & 440 & & \\
$\mathrm{NO}_{\mathrm{y}}$ (as NO & & & \\
$\mathrm{SO}_{2}$ (GA Tech) & 910 & & \\
$\mathrm{AMS} \mathrm{SO}_{4}$ & 4500 & & \\
$\mathrm{SO}_{2}+\mathrm{SO}_{4}$ & 280 & $600-650$ & \\
$\mathrm{AMS} \mathrm{OA}$ & 4800 & & 3100 \\
$\mathrm{AMS}$ total & 260 & $550-750$ & \\
$\mathrm{BC}$ (from PSAP) & 600 & & \\
$\mathrm{CO}$ & 9 & $0.5-5$ & \\
$\mathrm{CO}$ & 2100 & $1800-4000$ & 290 \\
\hline
\end{tabular}

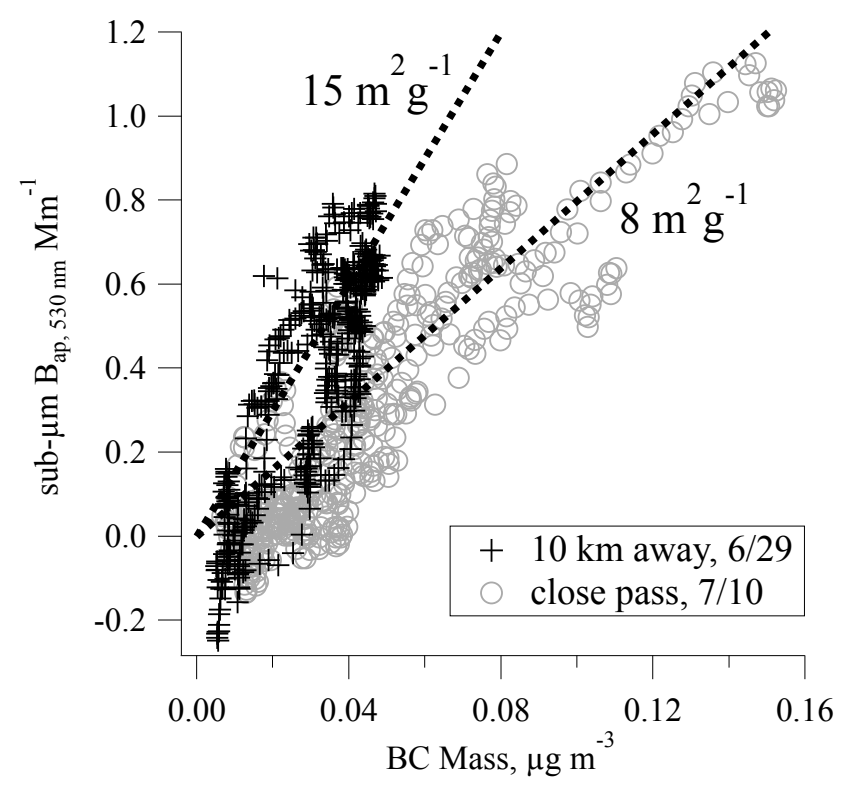

Figure 9. Relationship between $\mathrm{BC}$ mass and aerosol light absorption from the P-3B from directly over the upgrader facilities (10 July) and from about $10 \mathrm{~km}$ downwind (29 June). One-second data have been smoothed with a 21-point box filter, and periods on 10 July where the PSAP fluctuated wildly due to humidity transitions in the plumes have been eliminated. The dotted lines are not fits to the data; they are shown to illustrate that the data obtained were similar to literature values for uncoated $\left(8 \mathrm{~m}^{2} \mathrm{~g}^{-1}\right)$ and coated $\left(15 \mathrm{~m}^{2} \mathrm{~g}^{-1}\right)$ soot.

particles with soot cores surrounded by nonabsorbing coatings (Bond et al., 2006) and is similar to laboratory studies of coated soot (Schnaiter et al., 2005). Note that if soot particles were initially too small for the SP2 to detect but grew due to coagulation, the opposite pattern would be seen, as the PSAP would detect absorption from BC missed by the SP2, artificially raising the MAE in the near field. Another potential artifact could be caused by formation of "brown carbon" (BrC), nonsoot organic material capable of absorbing light (Andreae and Gelencser, 2006; Sun et al., 2007). This possibility can be examined by analyzing the wavelength dependence of absorption: $\mathrm{BC}$ absorption is inversely proportional to the wavelength, while $\mathrm{BrC}$ has a stronger relationship, absorbing little at long wavelengths and much more strongly at short wavelengths. During the 29 June flyby, the PSAP sampling sub- $\mu \mathrm{m}$ particles showed the pattern expected for BC. Meanwhile, the PSAP sampling all particle sizes did detect enhanced absorption at short wavelengths, which is characteristic of dust as well as BrC (Yang et al., 2009).

Table 2 enumerates most of the errors. "Instrument gaps" refer to how well the instrument can sample plume extremes. The AMS, for example, is blanking $25 \%$ of the time and so might miss peak concentrations. Convection out of the mixed layer is clearly visible in the lidar curtain (Fig. 7) between 18:04 and 18:06 and by the P-3B when it is over 
$2.3 \mathrm{~km}$ (Fig. 4) but is sporadic and thus hard to quantify. The maximum error would be if such an updraft were lofting part of the plume for the entire hour between emission and the flyby. The clouds were weak and so are likely to have updrafts $<0.1 \mathrm{~m} \mathrm{~s}^{-1}$ (anonymous reviewer \#1, personal communication, 2013). Over an hour, that would exhaust $360 \mathrm{~m}$ of the $900 \mathrm{~m}$ mixed layer, for a $40 \%$ maximal loss. Dry deposition losses are not included because they are relatively small; even a deposition velocity of $1 \mathrm{~cm} \mathrm{~s}^{-1}$ would remove $<4 \%$ of the column amount in the hour between emission and the DC-8 sampling. $\mathrm{NO}_{2}$ and $\mathrm{SO}_{2}$ also have photochemical sinks, but $\leq 6 \%$ per hour for $\mathrm{SO}_{2}$ (Cheng et al., 1987).

Environment Canada maintains a public website with historic emissions information. A search for $\mathrm{SO}_{2}$ emissions in 2008 reveals that the Syncrude and Suncor plants at Fort McMurray together released about $1 \times 10^{7} \mathrm{~kg}$ in 2008 , or $3100 \mathrm{~g} \mathrm{~s}^{-1}$. Given our estimated errors and the questionable assumption that $\mathrm{SO}_{2}$ production on 10 July were representative of annual emissions, the combined $\mathrm{SO}_{2}$ and $\mathrm{SO}_{4}$ fluxes of $4800 \mathrm{~g} \mathrm{~s}^{-1}$ constitute excellent agreement. $\mathrm{NO}_{\mathrm{y}}$ is even closer. The dramatic differences between reported and measured fluxes for $\mathrm{CO}$ are thus something of a surprise. $\mathrm{CO}_{2}$ fluxes were also higher than expected, but by a factor of 2.5 .

Even though this was a single snapshot and cannot be assumed to be representative, the agreement of measured $\mathrm{SO}_{2}+\mathrm{SO}_{4}$ and $\mathrm{NO}_{\mathrm{x}}$ fluxes with the Environment Canada database is probably not fortuitous; the upgraders run essentially continuously, are by far the dominant reported sources in the area, and are likely to dwarf undocumented emissions (only large stationary sources are in the database). Those conditions may be less true for $\mathrm{OM}, \mathrm{CO}, \mathrm{CO}_{2}$, and $\mathrm{BC}$.

Fluxes of gases and aerosols have often been measured from aircraft using calculations similar to Eq. (2), (e.g., White et al., 1976; Ryerson et al., 1998, 2011). Since those flight plans were designed for the purpose, with multiple plume penetrations and more extensive vertical structure measurements, they often reported much smaller uncertainties. Such improvements would be entirely practical in this region. Perhaps most valuable would be a lidar curtain directly over the flux-measurement legs, which could address three of the four largest uncertainties: mixed-layer depth, mixed-layer uniformity, and losses from the mixed layer. In fact, given some knowledge about aerosol optical properties and wind speed, a lidar alone can be used to measure aerosol fluxes (or anything a lidar can measure well) even with poorly mixed plumes (e.g., Porter et al., 2002). At best, flux calculation accuracy would probably be limited by aerosol or gas measurement errors and knowledge of wind velocity profiles.

Because they are unaffected by dilution, emission ratios can be determined with better precision than fluxes. Table 3 shows emission ratios of the aerosol species to $\mathrm{CO}$ from this work and from fresh forest fire plumes during ARCTAS. At the $10 \mathrm{~km}$ DC- 8 distance from the source, emission ratios were similar for $\mathrm{OA}$, but $\mathrm{BC}$ is enhanced in the oil sands plume about 3 times more, and $\mathrm{SO}_{4}$ : $\mathrm{CO}$ is higher by a factor of 50. However, the average $\mathrm{CO}$ enhancement in the oil sands plume averaged $10.3 \mathrm{ppbv}$ and peaked at $98 \mathrm{ppbv}$, while forest fire peaked an order of magnitude higher, so OA in fire plumes often reached hundreds of $\mu \mathrm{g} \mathrm{m}^{-3}$ (Cubison et al., 2011; Hecobian et al., 2011). Similarly, BC in the oil sands plume is small compared with even a single fire plume. It could be argued that using $\mathrm{CO}$ as the standard here is not ideal, since the large discrepancy between measured and reported $\mathrm{CO}$ fluxes reveals that we do not really understand the relationship between $\mathrm{CO}$ and other emissions from oil sands processing. Unfortunately, no good alternatives are available: the ideal denominator would be measured on both aircraft, present in both sources, and stable on the timescales of the sampling. CO does have the advantage that it is commonly used as a standard in biomass burning plumes.

Comparisons between the oil sands plume and other aerosol sources suffer from some ambiguity, as results are strongly dependent on the temporal and spatial scales chosen. As an arbitrary example, Table 4 shows estimated annual emissions from forest fires throughout Canada from Amiro et al. (2009) in comparison to the oil sands fluxes from Table 1. On this scale the oil sands are an insignificant source of $\mathrm{BC}, \mathrm{OA}$, and $\mathrm{CO}$ (even though we found much higher $\mathrm{CO}$ than expected), but they still dwarf fire production of $\mathrm{SO}_{2}$. Two caveats should be noted here: $\mathrm{BC}$ and OA have no precise chemical definition, so there are likely to be components of each that are primarily from the oil sands; and the fire season lasts only a couple of months, so aerosol from oil sands processing is certainly a more significant fraction of the total burden in other seasons.

\subsection{Aerosol evolution}

The P-3B and DC-8 flights near the sources on 10 July were the primary measurements for the oil sands emissions. However, we also encountered the plume downwind at other times as shown in Fig. 3. These "encounters of opportunity" provide data to examine plume development over time and some evolution in gas and aerosol properties.

Figure 10 shows P-3B data for the 29 June and 28 June flight segments, about 10 and $180 \mathrm{~km}$ downwind of the upgraders. Unfortunately, on 29 June, the CO went through a calibration cycle at exactly the peak of the plume. The $\mathrm{SO}_{4}$ peak that day was much smaller than on 10 July, indicating that the plane may have missed the main part of the plume or that $\mathrm{SO}_{2}$ production was lower that day. As with the DC-8 data discussed above and collected at roughly the same distance, the plume in Fig. 10a is complex, indicating a variety of sources. OA appears to have a much higher background, perhaps of biogenic origin as $\mathrm{BC}$ was low. A broad plume with dust and organic aerosol from 22:38 to 22:40 may correspond to mining operations and the evaporative plume from Simpson et al. (2010). The enhanced $\mathrm{SO}_{4}$ and very large UCN around 22:42 indicate the upgrader plume. As with the 
Table 2. Flux error estimates. Total errors are calculated by taking the square root of the sum of the squares of the individual errors. Totals are asymmetrical because losses from the mixed layer are not included in the flux calculation but could have had an effect.

\begin{tabular}{lrrrrrr}
\hline Error & $\mathrm{AMS}$ & $\mathrm{BC}$ & $\mathrm{NO}_{2}$ & $\mathrm{SO}_{2}$ & $\mathrm{CO}$ & $\mathrm{CO}_{2}$ \\
\hline Instrument accuracy & $35 \%$ & $50 \%$ & $10 \%$ & $10 \%$ & $2 \%$ & $0.1 \%$ \\
Clean/plume difference & $5 \%$ & $5 \%$ & $5 \%$ & $2 \%$ & $20 \%$ & $5 \%$ \\
Instrument gaps & $5 \%$ & $0 \%$ & $5 \%$ & $0 \%$ & $0 \%$ & $5 \%$ \\
Mixed-layer height & \multicolumn{5}{c}{$50 \%$} \\
Mixed-layer uniformity & \multicolumn{5}{c}{$\begin{array}{c}\text { Assume } 30 \% \\
\text { Wind speed } \\
\text { Loss from mixed layer }\end{array}$} & \multicolumn{5}{c}{$+40 \%,-0 \%$} & & \\
\hline Total & $+85 \%$ & $+90 \%$ & $+80 \%$ & $+75 \%$ & $+80 \%$ & $+75 \%$ \\
& $-75 \%$ & $-85 \%$ & $-70 \%$ & $-65 \%$ & $-70 \%$ & $-65 \%$ \\
\hline
\end{tabular}
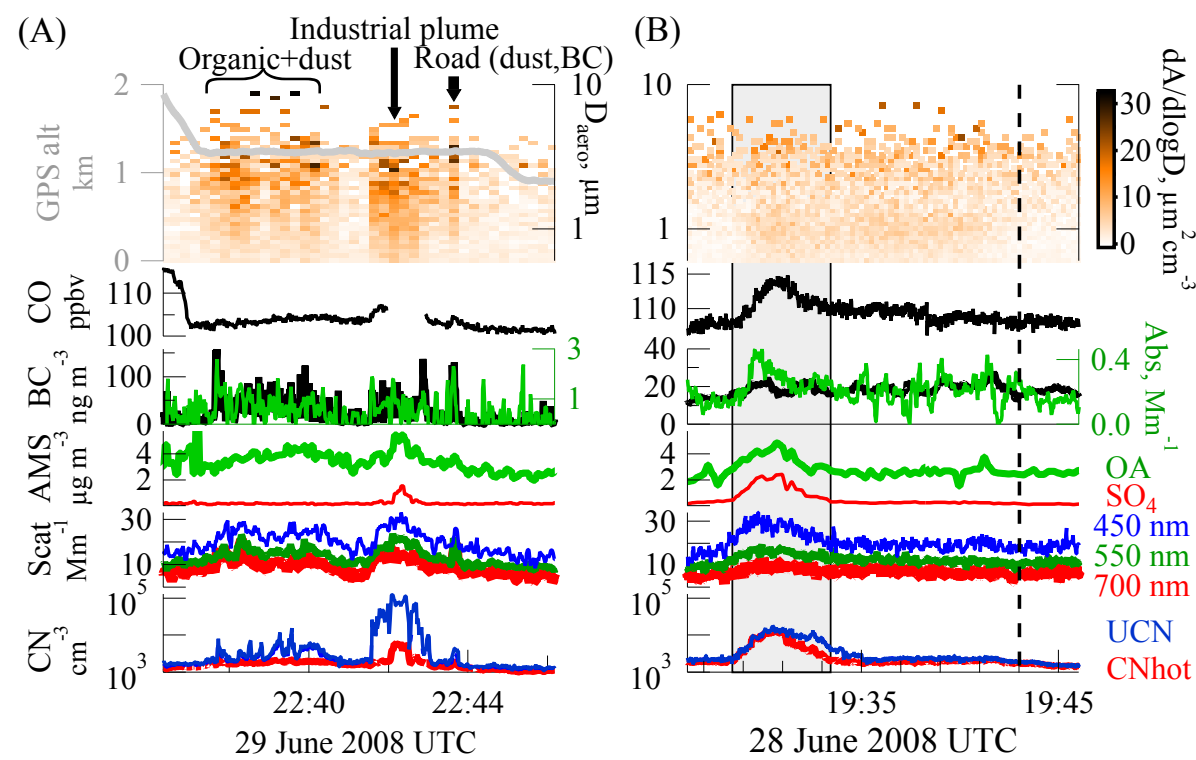

Figure 10. P-3B crossings of the oil sands plume at (A) about $10 \mathrm{~km}$ (on 29 June) and (B) about $180 \mathrm{~km}$ (28 June) from the upgraders. Vertical scales are the same on both plots except for CO, BC, and absorption. Absorption is for $530 \mathrm{~nm}$ light. The gap in CO data around 22:42 on 29 June was due to an automatic calibration cycle. Altitude on 28 June was constant at $1200 \mathrm{~m}$, so it is not shown. Low BC and absorption rendered the data sufficiently noisy that a $21 \mathrm{~s}$ box filter was applied to make changes visible. The gray region shows the minimal plume period used to calculate fluxes in Table 1, defined by the enhanced $\mathrm{SO}_{4}$. The vertical dashed line marks the end of the maximum plume period, determined from $\mathrm{BC}$ and the $1 \mu \mathrm{m}$ mode visible in the APS data.

Table 3. Aerosol enhancement ratios relative to $\mathrm{CO}$. Units are $\mathrm{mg}$ aerosol $(\mathrm{gCO})^{-1}$. Forest fire data are from fresh plumes observed during ARCTAS (Singh et al., 2010).

\begin{tabular}{lcr}
\hline Species & Oil sands & Forest fires \\
\hline $\mathrm{OA}$ & $120 \pm 60$ & $120 \pm 50$ \\
$\mathrm{SO}_{4}$ & $130 \pm 60$ & $2.4 \pm 1.4$ \\
$\mathrm{BC}$ & $4.3 \pm 2.3$ & $1.6 \pm 0.9$ \\
\hline
\end{tabular}

10 July data, most of the particles are volatile and thus not detected as CNhot. A review of the forward video reveals that the very narrow peak at 22:43:39 occurred shortly af- ter the plane flew over a road where trucks could be seen raising clouds of dust. Dust was responsible for much of the light scattering seen throughout the plume crossing; the very similar patterns at all wavelengths can only occur with particles large compared to the wavelength. While $\mathrm{SO}_{4}$ was far smaller than that seen by the DC-8 a similar distance away, the dust seen by the APS was similar, though the $1 \mu \mathrm{m}$ mode was absent, further evidence that the plane either missed part of the plume or that the industrial facilities were operating differently.

In contrast to the detail visible at $10 \mathrm{~km}$, the plume at $180 \mathrm{~km}$ downwind (Fig. 10b) is broad and smooth. Wind speeds were about $10 \mathrm{~ms}^{-1}$, so the plume was about $5 \mathrm{~h}$ old. The dust is no longer obvious, presumably diluted rather 
Table 4. Emissions from the oil sands in comparison to estimated forest fire production. $\mathrm{BC}, \mathrm{NO}_{\mathrm{y}}$, and $\mathrm{CO}$ are directly from Amiro et al. (2009), while the others use ratios to CO during fire plume penetrations in ARCTAS (as identified by acetonitrile $>0.5 \mathrm{ppbv}$ ). Units are $\mathrm{Gg} \mathrm{yr}^{-1}$. The $\mathrm{SO}_{4}$ numbers are a bit misleading, as some of the $\mathrm{SO}_{2}$ will react to create more sulfate.

\begin{tabular}{lrrr}
\hline Species & Oil sands & Forest fires & OS:FF \\
\hline $\mathrm{BC}$ & 0.3 & 34 & $1 \%$ \\
$\mathrm{NO}_{\mathrm{y}}$ & 29 & 181 & $16 \%$ \\
$\mathrm{CO}$ & 66 & 6450 & $1 \%$ \\
$\mathrm{SO}_{4}$ & 9 & 13 & $70 \%$ \\
$\mathrm{SO}_{2}$ & 140 & 13 & $1000 \%$ \\
$\mathrm{OA}$ & 8 & 900 & $1 \%$ \\
\hline
\end{tabular}

than sedimented out, as dry deposition timescales are about $12 \mathrm{~h}$ for $5 \mu \mathrm{m}$ particles, which have a deposition velocity of roughly $2 \mathrm{~cm} \mathrm{~s}^{-1}$ in coniferous forests with that wind speed (Zhang et al., 2001). However, the roughly $1 \mu \mathrm{m}$ possible fly ash mode is evident. The disparity between the red and blue channels reveals that small particles now dominate the scattering. While overall particle concentrations are lower (note the $\log$ scales on the $\mathrm{CN}$ data), there are now very few volatile particles, and higher CNhot suggests that at least some of the secondary organic material in the aerosol has low volatility. Once again, $\mathrm{SO}_{4}$ and $\mathrm{OA}$ are well correlated. $\mathrm{CO}$, which is stable at these timescales, rises about 6 ppbv.

Flux calculations like those in Sect. 3.3 can be be applied here, though errors are even more poorly quantified: the mixed-layer top of $2900 \mathrm{~m}$ is solely from a descent prior to the plume crossing; the P-3B wind speeds were compromised by the radiometer on the nose of the aircraft; and the end time of the plume is rather ambiguous: if the plume is defined by elevated $\mathrm{SO}_{4}$, the penetration took $5 \mathrm{~min}$, while the $\mathrm{BC}$ suggests that the crossing took $15 \mathrm{~min}$. It is likely that the $\mathrm{SO}_{4}$ plume is from the industrial facilities while the $\mathrm{BC}$ is from a broader range of sources, some of which may not be associated with the oil sands. Thus, these fluxes are just rough estimates. Table 1 shows the range of fluxes calculated for reasonable definitions of the end of the plume. Values for $\mathrm{SO}_{4}$ and $\mathrm{OA}$ do not change much in this calculation, while $\mathrm{BC}$ and $\mathrm{CO}$ are sensitive to the plume duration and are particularly uncertain.

While very approximate, the fluxes calculated in this flyby do confirm the high $\mathrm{CO}$ emissions from the DC-8 loop. The increased $\mathrm{SO}_{4}: \mathrm{CO}$ is as expected, since sulfate production from $\mathrm{SO}_{2}$ continues while $\mathrm{CO}$ is inert at these timescales. If $\mathrm{SO}_{2}$ emissions were the same those two days, then the additional 320 to $370 \mathrm{~g} \mathrm{~s}^{-1}$ represents about $8 \%$ of the $\mathrm{SO}_{2}$ in the roughly $5 \mathrm{~h}$ since emission, still more than can be attributed to reaction with $0.1 \mathrm{pptv} \mathrm{OH}$.

The correlation between $\mathrm{OA}$ and $\mathrm{SO}_{4}$ at 10 and $180 \mathrm{~km}$ and during the $\mathrm{P} 3-\mathrm{B}$ downwind leg reinforce the idea that $\mathrm{SO}_{4}$ production governs secondary $\mathrm{OA}$ formation through ei-

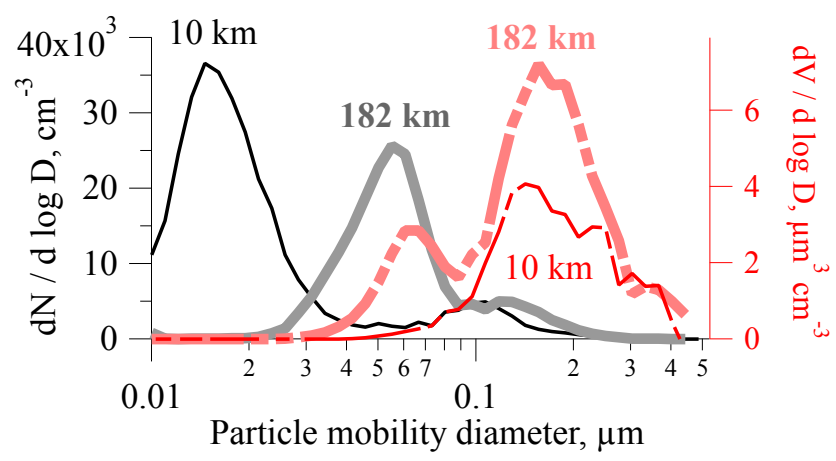

Figure 11. SMPS number and volume size distributions obtained 10 and $180 \mathrm{~km}$ from the source.

ther acid-catalyzed polymerization or organosulfate production. The relative isolation of the oil sands plume and its high acidity may provide an excellent opportunity to study these reactions outside of a laboratory environment.

The increased small particle scattering in Fig. 10b is due to growth of particles initially too small to affect visible light. This is revealed by comparing SMPS distributions obtained in each plume. In Fig. 11 we compare number distributions measured near the source ( $10 \mathrm{~km}$ downwind, black) with several distributions measured at 172 to $192 \mathrm{~km}$ downwind (red). The mean of the latter (heavy dashed red) has a peak near $0.06 \mu \mathrm{m}$ compared to $0.015 \mu \mathrm{m}$ near the source. This indicates that some sizes near the source were too small to be active as $\mathrm{CCN}$ in BL clouds but have grown to be effective CCN (i.e., larger than about $0.06 \mu \mathrm{m}$ ) for low clouds. Corresponding growth in the larger mode near $0.1 \mu \mathrm{m}$ is also evident, but, as most in this mode were also larger than $0.06 \mu \mathrm{m}$ before aging, this growth strongly affects light scattering but has only a second-order effect on their effectiveness as CCN.

As shown in Fig. 3, the DC-8 also intercepted the plume on 29 June. It was inadvertent; the plan was to sample a fire plume seen the previous day. The low-altitude sampling leg was cut short when no smoke was found. However, elevated $\mathrm{SO}_{2}$ and $\mathrm{NO}_{\mathrm{y}}$ suggest the oil sands plume was present (Fig. 12). A variety of hydrocarbons were also detected, consistent with those identified in the oil sands plume by Simpson et al. (2010). This was not a forest fire plume - CO was only slightly enriched and other biomass indicators like $\mathrm{HCN}$ were not elevated at all. The gas ratios did not resemble those identified in the Simpson et al. (2011) analysis of boreal forest fire plumes.

Low-altitude winds and back trajectories are consistent with transport from the Ft. McMurray area (Fig. 13). Trajectories from the southern end of the leg did pass directly over the upgraders about $5 \mathrm{~h}$ earlier, but at an altitude $1400 \mathrm{~m}$ above the facilities. Low-altitude winds evidently carried the plume north for a few hours before lofting it to $900 \mathrm{~m}$, where the back trajectories led to the northern end of the flight leg. 


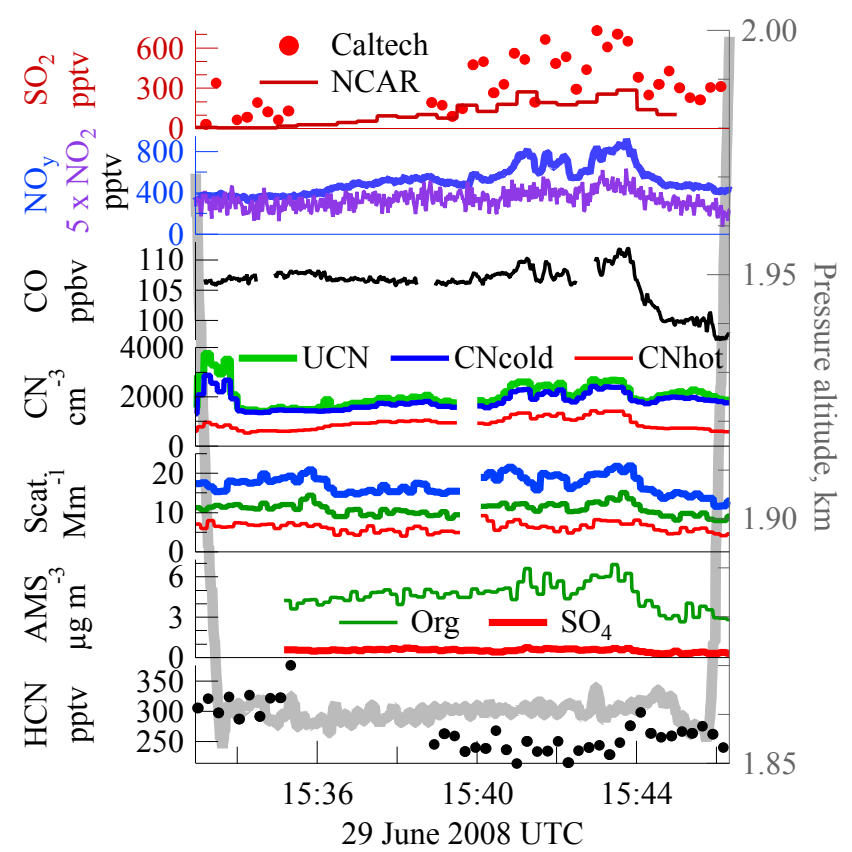

Figure 12. DC-8 plume interception on 29 June. $\mathrm{NO}_{2}, \mathrm{NO}_{\mathrm{y}}$, and $\mathrm{SO}_{2}$ are consistent with the oil sands plume; low $\mathrm{HCN}$ and minimally enriched $\mathrm{CO}$ indicate that this is not a fire plume.

However, the aerosol signature usually present in the oil sands plume was weak. $\mathrm{CN}$ and scattering rose only slightly. More surprisingly, while AMS OA correlated well with $\mathrm{SO}_{2}$, $\mathrm{NO}_{\mathrm{y}}$, and organic vapors, the $\mathrm{OA}: \mathrm{SO}_{4}$ ratio was $8: 1$ rather than $1: 1$. This suggests some removal mechanism, rather than simply dilution, was active. Rain was reported at Ft. McMurray at 2 and 3 a.m local time (09:00 and 10:00 UTC) on 29 June (Environment Canada, 2008b), about $7 \mathrm{~h}$ before the DC-8 flight. One likely explanation is that much of the $\mathrm{SO}_{2}$ reacted in cloud to form $\mathrm{SO}_{4}$, which was effectively removed by rain, while leaving insoluble organic vapors unaffected. Photochemical reactions after sunrise could then produce the organic aerosol seen in Fig. 12.

\section{Conclusions}

While 2 flybys and 3 incidental plume penetrations can only provide short-term estimates of the aerosol output of the Alberta oil sands mining and upgrading operations, these flights have established that emissions fluxes can be measured, at least under favorable weather conditions, but with uncertainties of about a factor of 2 . The primary sources of error are mixed-layer depth and homogeneity and exchange with overlying air. Careful flight planning, extended sampling including multiple altitudes, and lidar data along the flux cross section could greatly enhance the accuracy of the flux calculations, probably to within $50 \%$.

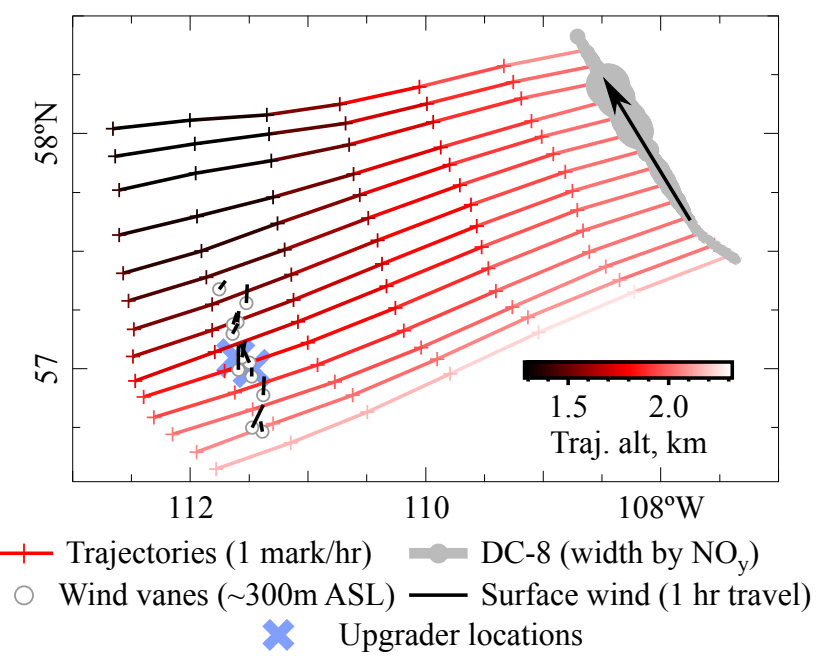

Figure 13. Low-altitude winds and back trajectories to the DC-8 flight track on 29 June. Kinematic back trajectories are from the Florida State University group and are driven by hourly FSU/WRF winds on a $45 \mathrm{~km}$ grid initialized from GFS. Surface winds are from ground stations at about $5 \mathrm{~h}$ before the DC- 8 flight.

$\mathrm{SO}_{2}$ and $\mathrm{NO}_{2}$ emission inventories lie within error estimates of our calculated flux, though our measurements of $\mathrm{CO}$ fluxes substantially exceeded reported emissions during two plume penetrations. $\mathrm{CO}_{2}$ emissions were also above reported emissions, but not by a large factor. Black carbon fluxes are highly uncertain, but appear to be roughly $10 \mathrm{~g} \mathrm{~s}^{-1}$.

While neither the mining operations nor the industrial facilities produce much particulate organic matter directly, organic aerosol appears rapidly within the industrial plume in a short time, creating particulate mass approximately equal to the sulfate. Some of this may be primary OA, due to condensation of vapors as the plume cools, but reactions between $\mathrm{H}_{2} \mathrm{SO}_{4}$ and either biogenic or plume-derived organic vapors may be important. At least over short ranges, we confirm the $\mathrm{SO}_{2}$ photochemical loss rates from Cheng et al. (1987), though reaction with $\mathrm{OH}$ appears insufficient to account for the conversion rate to $\mathrm{SO}_{4}$.

The industrial plume has tremendously high aerosol number concentrations, saturating our counting instruments, but those particles are too small to scatter light or serve as effective $\mathrm{CCN}$. They do coagulate and grow, so by the time the plume is a few hours old $\mathrm{CCN}$ concentrations and scattering are affected. Major light scattering components of the aerosol are the accumulation mode in the industrial plume, dust, and what appears to be fly ash.

Compared to estimates of annual forest fire emissions in Canada, the oil sands facilities are a minor source of aerosol number, aerosol mass, particulate organic matter, and black carbon. They produce roughly comparable sulfate aerosol and far more sulfur dioxide. 
Acknowledgements. We thank H. Maring (NASA) for his support of this objective and some of the analysis undertaken here as part of our NASA grant NNX08AD39G. M. J. Cubison and J.L. Jimenez were supported by NASA grants NNX08AD39G and NNX12AC03G. We also appreciate the data collected and assembled by other P3B and DC-8 researchers during ARCTAS that appear or underlie some of the data/information referenced here. The authors also thank the NASA P3B and DC-8 support staff and their assistance in collecting this data. We particularly appreciate the interest and support of the Clean Air Task Force and Ellen Baum in helping purchase our SP2 used in ARCTAS and for the partial support provided for preparation of this report.

This is SOEST contribution 8982.

Edited by: J. Liggio

\section{References}

Aiken, A. C., DeCarlo, P. F., Kroll, J. H., Worsnop, D. R., Huffman, J. A., Docherty, K. S., Ulbrich, I. M., Mohr, C., Kimmel, J. R., Sueper, D., Sun, Y., Zhang, Q., Trimborn, A., Northway, M., Ziemann, P. J., Canagaratna, M. R., Onasch, T. B., Alfarra, M. R., Prevot, A. S. H., Dommen, J., Duplissy, J., Metzger, A., Baltensperger, U., and Jimenez, J. L.: O/C and OM/OC ratios of primary, secondary, and ambient organic aerosols with highresolution time-of-flight aerosol mass spectrometry, Environ. Sci. Technol., 42, 4478-4485, doi:10.1021/es703009q, 2008.

Alboudwarej, H., Felix, J., Taylor, S., Badry, R., Bremner, C., Brough, B., Skeates, C., Baker, A., Palmer, D., Anchorage, K. P., Beshry, M., Krawchuk, P., Brown, G., Calvo, R., Triana, J. A. C., Hathcock, R., Koerner, K., Hughes, T., Kundu, D., de Cárdenas, J. L., and West, C.: Highlighting Heavy Oil, Schlumberger Oilfield Review, 18, 34-53, http://www.slb.com/ /media/ Files/resources/oilfield_review/ors06/sum06/heavy_oil.pdf (last access: 9 August 2013), 2006.

Allan, J. D., Jimenez, J. L., Williams, P. I., Alfarra, M. R., Bower, K. N., Jayne, J. T., Coe, H., and Worsnop, D. R.: Quantitative sampling using an Aerodyne aerosol mass spectrometer: 1. Techniques of data interpretation and error analysis, J. Geophys. Res, 108, 4090, doi:10.1029/2002JD002358, 2003.

Allan, J. D., Delia, A. E., Coe, H., Bower, K. N., Alfarra, M., Jimenez, J. L., Middlebrook, A. M., Drewnick, F., Onasch, T. B., Canagaratna, M. R., Jayne, J. T., and Worsnop, D. R.: A generalised method for the extraction of chemically resolved mass spectra from Aerodyne aerosol mass spectrometer data, J. Aerosol. Sci., 35, 909-922, doi:10.1016/j.jaerosci.2004.02.007, 2004

Amiro, B. D., Cantin, A., Flannigan, M. D., and de Groot, W. J.: Future emissions from Canadian boreal forest fires, Can. J. Forest Res., 39, 383-395, doi:10.1139/X08-154, 2009.

Anderson, T. L. and Ogren, J. A.: Determining Aerosol Radiative Properties Using the TSI 3563 Integrating Nephelometer, Aerosol Sci. Tech., 29, 57-69, doi:10.1080/02786829808965551, 1998.

Anderson, T. L., Covert, D. S., Marshall, S. F., Laucks, M. L., Charlson, R. J., Waggoner, A. P., Ogren, J. A., Caldow, R., Holm, R. L., Quant, F. R., Sem, G. J., Wiedensohler, A., Ahlquist, N. A., and Bates, T. S.: Performance Characteristics of a High-Sensitivity, Three-Wavelength, Total Scatter/Backscatter Nephelometer,
J. Atmos. Ocean. Tech., 13, 967-986, doi:10.1175/1520 0426(1996)013<0967:PCOAHS>2.0.CO;2, 1996.

Andreae, M. O. and Gelencsér, A.: Black carbon or brown carbon? The nature of light-absorbing carbonaceous aerosols, Atmos. Chem. Phys., 6, 3131-3148, doi:10.5194/acp-6-3131-2006, 2006.

Bahreini, R., Dunlea, E. J., Matthew, B. M., Simons, C., Docherty, K. S., DeCarlo, P. F., Jimenez, J. L., Brock, C. A., and Middlebrook, A. M.: Design and Operation of a Pressure Controlled Inlet for Airborne Sampling with an Aerodynamic Aerosol Lens, Aerosol Sci. Tech., 42, 465-471, 2008.

Baron, P. A. and Willeke, K.: Aerosol measurement: principles, techniques, and applications, Wiley New York, 2001.

Barrie, L. A.: The Fate Of Particulate Emissions From An Isolated Power Plant In The Oil Sands Area Of Western Canada, Ann. NY Acad. Sci., 338, 434-452, 1980.

Blitz, M. A., Hughes, K. J., and Pilling, M. J.: Determination of the High-Pressure Limiting Rate Coefficient and the Enthalpy of Reaction for $\mathrm{OH}+\mathrm{SO}_{2}$, J. Phys. Chem. A, 107, 1971-1978, doi:10.1021/jp026524y, 2003.

Bond, T. C. and Bergstrom, R. W.: Light Absorption by Carbonaceous Particles: An Investigative Review, Aerosol Sci. Tech., 40, 27-67, doi:10.1080/02786820500421521, 2006.

Bond, T. C., Habib, G., and Bergstrom, R., W.: Limitations in the enhancement of visible light absorption due to mixing state, $\mathbf{J}$ Geophys. Res., 111, D20211, doi:10.1029/2006JD007315, 2006.

Browell, E. V., Ismail, S., and Grant, W. B.: Differential absorption lidar (DIAL) measurements from air and space, Appl. Phys. BLasers O., 67, 399-410, doi:10.1007/s003400050523, 1998.

Cheng, L., Peake, E., and Davis, A.: The Rate of $\mathrm{SO}_{2}$ to Sulfate Particle Formation in an Air Parcel from an Oil Sands Extraction Plant Plume, JAPCA J. Air Waste Ma., 37, 163-167, doi:10.1080/08940630.1987.10466211, 1987.

Clarke, A., McNaughton, C., Kapustin, V., Shinozuka, Y., Howell, S., Dibb, J., Zhou, J., Anderson, B., Brekhovskikh, V., Turner, H., and Pinkerton, M.: Biomass burning and pollution aerosol over North America: Organic components and their influence on spectral optical properties and humidification response, J. Geophys. Res., 112, D12S18, doi:10.1029/2006JD007777, 2007.

Clarke, A. D.: A Thermo-optic Technique for in situ Analysis of Size-resolved Aerosol Physicochemistry, Atmos. Environ., 25A, 635-644, 1991.

Clarke, A. D., Varner, J. L., Eisele, F., Mauldin, R. L., Tanner, D., and Litchy, M.: Particle production in the remote marine atmosphere: Cloud outflow and subsidence during ACE 1, J. Geophys. Res., 103, 16397-16409, doi:10.1029/97JD02987, 1998.

Cubison, M. J., Ortega, A. M., Hayes, P. L., Farmer, D. K., Day, D., Lechner, M. J., Brune, W. H., Apel, E., Diskin, G. S., Fisher, J. A., Fuelberg, H. E., Hecobian, A., Knapp, D. J., Mikoviny, T., Riemer, D., Sachse, G. W., Sessions, W., Weber, R. J., Weinheimer, A. J., Wisthaler, A., and Jimenez, J. L.: Effects of aging on organic aerosol from open biomass burning smoke in aircraft and laboratory studies, Atmos. Chem. Phys., 11, 12049-12064, doi:10.5194/acp-11-12049-2011, 2011.

Davies, M.: Air Quality Modeling in the Athabasca Oil Sands Region, in: Alberta Oil Sands, edited by: Percy, K. E., vol. 11 of Developments in Environmental Science, chap. 12, 267-309, Elsevier, doi:10.1016/B978-0-08-097760-7.00012-3, 2012. 
DeCarlo, P. F., Kimmel, J. R., Trimborn, A., Northway, M. J., Jayne, J. T., Aiken, A. C., Gonin, M., Fuhrer, K., Horvath, T., Docherty, K. S., Worsnop, D. R., and Jimenez, J. L.: Field-deployable, high-resolution, time-of-flight aerosol mass spectrometer, Anal. Chem, 78, 8281-8289, doi:10.1021/ac061249n, 2006.

Dupont, R., Pierce, B., Worden, J., Hair, J., Fenn, M., Hamer, P., Natarajan, M., Schaack, T., Lenzen, A., Apel, E., Dibb, J., Diskin, G., Huey, G., Weinheimer, A., Kondo, Y., and Knapp, D.: Attribution and evolution of ozone from Asian wild fires using satellite and aircraft measurements during the ARCTAS campaign, Atmos. Chem. Phys., 12, 169-188, doi:10.5194/acp-12169-2012, 2012.

Environment Canada: National Pollutant Release Inventory Facility Data Search-Alberta Oilsands and Heavy Oil, http://www.ec.gc. ca/inrp-npri/donnees-data/index.cfm?lang=En (last access: May 2014), 2008a.

Environment Canada: National Climate Data and Information Archive, http://www.climate.weather.gc.ca/climateData/ hourlydata_e.html?timeframe=1\&Prov=ALTA $\&$ StationID $=$ 2519\&hlyRange=1953-01-01|2008-09-25\&Year= 2008\&Month=6\&Day=29 (last access: May 2014), 2008b.

Farmer, D. K., Matsunaga, A., Docherty, K. S., Surratt, J. D., Seinfeld, J. H., Ziemann, P. J., and Jimenez, J. L.: Response of an aerosol mass spectrometer to organonitrates and organosulfates and implications for atmospheric chemistry, P. Natl. Acad. Sci. USA, 107, 6670-6675, doi:10.1073/pnas.0912340107, 2010.

Fuller, K. A., Malm, W. C., and Kreidenweis, S. M.: Effects of mixing on extinction by carbonaceous particles, J. Geophys. Res., 104, 15941-15954, doi:10.1029/1998JD100069, 1999.

Hecobian, A., Liu, Z., Hennigan, C. J., Huey, L. G., Jimenez, J. L., Cubison, M. J., Vay, S., Diskin, G. S., Sachse, G. W., Wisthaler, A., Mikoviny, T., Weinheimer, A. J., Liao, J., Knapp, D. J., Wennberg, P. O., Kürten, A., Crounse, J. D., Clair, J. St., Wang, Y., and Weber, R. J.: Comparison of chemical characteristics of 495 biomass burning plumes intercepted by the NASA DC-8 aircraft during the ARCTAS/CARB-2008 field campaign, Atmos. Chem. Phys., 11, 13325-13337, doi:10.5194/acp-1113325-2011, 2011

Jacob, D. J., Crawford, J. H., Maring, H., Clarke, A. D., Dibb, J. E., Emmons, L. K., Ferrare, R. A., Hostetler, C. A., Russell, P. B., Singh, H. B., Thompson, A. M., Shaw, G. E., McCauley, E., Pederson, J. R., and Fisher, J. A.: The Arctic Research of the Composition of the Troposphere from Aircraft and Satellites (ARCTAS) mission: design, execution, and first results, Atmos. Chem. Phys., 10, 5191-5212, doi:10.5194/acp-10-5191-2010, 2010.

Jang, M., Czoschke, N. M., Lee, S., and Kamens, R. M.: Heterogeneous Atmospheric Aerosol Production by AcidCatalyzed Particle-Phase Reactions, Science, 298, 814-817, doi:10.1126/science.1075798, 2002.

Kimmel, J. R., Farmer, D. K., Cubison, M. J., Sueper, D., Tanner, C., Nemitz, E., Worsnop, D. R., Gonin, M., and Jimenez, J. L.: Realtime aerosol mass spectrometry with millisecond resolution, Int. J. Mass. Spectrom., 303, 15-26, doi:10.1016/j.ijms.2010.12.004, 2011.

Littlejohn, D., Wang, Y., and Chang, S. G.: Oxidation of aqueous sulfite ion by nitrogen dioxide, Environ. Sci. Technol., 27, 21622167, doi:10.1021/es00047a024, 1993.

Liu, P. S. K., Deng, R., Smith, K. A., Williams, L. R., Jayne, J. T., Canagaratna, M. R., Moore, K., Onasch, T. B., Worsnop,
D. R., and Deshler, T.: Transmission Efficiency of an Aerodynamic Focusing Lens System: Comparison of Model Calculations and Laboratory Measurements for the Aerodyne Aerosol Mass Spectrometer, Aerosol Sci. Tech., 41, 721-733, doi:10.1080/02786820701422278, 2007.

Mahowald, N., Albani, S., Kok, J. F., Engelstaeder, S., Scanza, R., Ward, D. S., and Flanner, M. G.: The size distribution of desert dust aerosols and its impact on the Earth system, Aeolian Research, in press, doi:10.1016/j.aeolia.2013.09.002, 2014.

Maring, H., Savoie, D. L., Izaguirre, M. A., Custals, L., and Reid, J. S.: Mineral dust aerosol size distribution change during atmospheric transport, J. Geophys. Res., 108, 8592, doi:10.1029/2002JD002536, 2003.

McLinden, C. A., Fioletov, V., Boersma, K. F., Krotkov, N., Sioris, C. E., Veefkind, J. P., and Yang, K.: Air quality over the Canadian oil sands: A first assessment using satellite observations, Geophys. Res. Lett., 39, L04804, doi:10.1029/2011GL050273, 2012.

McNaughton, C. S., Clarke, A. D., Howell, S. G., Pinkerton, M., Anderson, B., Thornhill, L., Winstead, E., Hudgins, C., Dibb, J. E., Scheuer, E., and Maring, H.: Results from the DC-8 inlet characterization experiment (DICE): Airborne versus surface sampling of mineral dust and sea salt aerosols, Aerosol Sci. Tech., 41, 136-159, doi:10.1080/02786820601118406, 2007.

Middlebrook, A. M., Bahreini, R., Jimenez, J. L., and Canagaratna, M. R.: Evaluation of Composition-Dependent Collection Efficiencies for the Aerodyne Aerosol Mass Spectrometer using Field Data, Aerosol Sci. Tech., 46, 258-271, doi:10.1080/02786826.2011.620041, 2012.

Ng, N. L., Canagaratna, M. R., Jimenez, J. L., Zhang, Q., U1brich, I. M., and Worsnop, D. R.: Real-Time Methods for Estimating Organic Component Mass Concentrations from Aerosol Mass Spectrometer Data, Environ. Sci. Technol., 45, 910-916, doi:10.1021/es102951k, 2011.

Penkett, S. A., Jones, B. M. R., Brich, K. A., and Eggleton, A. E. J.: The importance of atmospheric ozone and hydrogen peroxide in oxidising sulphur dioxide in cloud and rainwater, Atmos. Environ., 13, 123-137, doi:10.1016/0004-6981(79)90251-8, 1979.

Porter, J. N., Horton, K. A., Mouginis-Mark, P. J., Lienert, B., Sharma, S. K., Lau, E., Sutton, A. J., Elias, T., and Oppenheimer, C.: Sun photometer and lidar measurements of the plume from the Hawaii Kilauea Volcano Pu 'u O'o vent: Aerosol flux and $\mathrm{SO}_{2}$ lifetime, Geophys. Res. Lett., 29, 30-1-30-4, doi:10.1029/2002GL014744, 2002.

Proemse, B. C., Mayer, B., Chow, J. C., and Watson, J. G.: Isotopic characterization of nitrate, ammonium and sulfate in stack PM2.5 emissions in the Athabasca Oil Sands Region, Alberta, Canada, Atmos. Environ., 60, 555-563, doi:10.1016/j.atmosenv.2012.06.046, 2012a.

Proemse, B. C., Mayer, B., and Fenn, M. E.: Tracing industrial sulfur contributions to atmospheric sulfate deposition in the Athabasca Oil Sands Region, Alberta, Canada, Appl. Geochem., 27, 2425-2434, doi:10.1016/j.apgeochem.2012.08.006, 2012b.

Ryerson, T. B., Buhr, M. P., Frost, G. J., Goldan, P. D., Holloway, J. S., Hübler, G., Jobson, B. T., Kuster, W. C., McKeen, S. A., Parrish, D. D., Roberts, J. M., Sueper, D. T., Trainer, M., Williams, J., and Fehsenfeld, F. C.: Emissions lifetimes and ozone formation in power plant plumes, J. Geophys. Res., 103, 22569-22583, doi:10.1029/98JD01620, 1998. 
Ryerson, T. B., Aikin, K. C., Angevine, W. M., Atlas, E. L., Blake, D. R., Brock, C. A., Fehsenfeld, F. C., Gao, R.-S., de Gouw, J. A., Fahey, D. W., Holloway, J. S., Lack, D. A., Lueb, R. A., Meinardi, S., Middlebrook, A. M., Murphy, D. M., Neuman, J. A., Nowak, J. B., Parrish, D. D., Peischl, J., Perring, A. E., Pollack, I. B., Ravishankara, A. R., Roberts, J. M., Schwarz, J. P., Spackman, J. R., Stark, H., Warneke, C., and Watts, L. A.: Atmospheric emissions from the Deepwater Horizon spill constrain air-water partitioning, hydrocarbon fate, and leak rate, Geophys. Res. Lett., 38, L07803, doi:10.1029/2011GL046726, 2011.

Sarwar, G., Fahey, K., Kwok, R., Gilliam, R. C., Roselle, S. J., Mathur, R., Xue, J., Yu, J., and Carter, W. P.: Potential impacts of two $\mathrm{SO}_{2}$ oxidation pathways on regional sulfate concentrations: Aqueous-phase oxidation by $\mathrm{NO}_{2}$ and gas-phase oxidation by Stabilized Criegee Intermediates, Atmos. Environ., 68, 186-197, doi:10.1016/j.atmosenv.2012.11.036, 2013.

Schnaiter, M., Linke, C., Möhler, O., Naumann, K. H., Saathoff, H., Wagner, R., Schurath, U., and Wehner, B.: Absorption amplification of black carbon internally mixed with secondary organic aerosol, J. Geophys. Res., 110, D19204, doi:10.1029/2005JD006046, 2005.

Schwarz, J. P., Gao, R. S., Fahey, D. W., Thomson, D. S., Watts, L. A., Wilson, J. C., Reeves, J. M., Darbeheshti, M., Baumgardner, D. G., Kok, G. L., Chung, S. H., Schulz, M., Hendricks, J., Lauer, A., Kärcher, B., Slowik, J. G., Rosenlof, K. H., Thompson, T. L., Langford, A. O., Loewenstein, M., and Aikin, K. C.: Single-particle measurements of midlatitude black carbon and light-scattering aerosols from the boundary layer to the lower stratosphere, J. Geophys. Res., 111, D16207, doi:10.1029/2006JD007076, 2006.

Shinozuka, Y., Redemann, J., Livingston, J. M., Russell, P. B., Clarke, A. D., Howell, S. G., Freitag, S., O’Neill, N. T., Reid, E. A., Johnson, R., Ramachandran, S., McNaughton, C. S., Kapustin, V. N., Brekhovskikh, V., Holben, B. N., and McArthur, L. J. B.: Airborne observation of aerosol optical depth during ARCTAS: vertical profiles, inter-comparison and fine-mode fraction, Atmos. Chem. Phys., 11, 3673-3688, doi:10.5194/acp-11-36732011, 2011.

Simpson, I. J., Blake, N. J., Barletta, B., Diskin, G. S., Fuelberg, H. E., Gorham, K., Huey, L. G., Meinardi, S., Rowland, F. S., Vay, S. A., Weinheimer, A. J., Yang, M., and Blake, D. R.: Characterization of trace gases measured over Alberta oil sands mining operations: 76 speciated $\mathrm{C}_{2}-\mathrm{C}_{10}$ volatile organic compounds (VOCs), $\mathrm{CO}_{2}, \mathrm{CH}_{4}, \mathrm{CO}, \mathrm{NO}, \mathrm{NO}_{2}, \mathrm{NO}_{\mathrm{y}}, \mathrm{O}_{3}$ and $\mathrm{SO}_{2}$, Atmos. Chem. Phys., 10, 11931-11954, doi:10.5194/acp-10-11931-2010, 2010.

Simpson, I. J., Akagi, S. K., Barletta, B., Blake, N. J., Choi, Y., Diskin, G. S., Fried, A., Fuelberg, H. E., Meinardi, S., Rowland, F. S., Vay, S. A., Weinheimer, A. J., Wennberg, P. O., Wiebring, P., Wisthaler, A., Yang, M., Yokelson, R. J., and Blake, D. R.: Boreal forest fire emissions in fresh Canadian smoke plumes: $\mathrm{C}_{1}-\mathrm{C}_{10}$ volatile organic compounds (VOCs), $\mathrm{CO}_{2}, \mathrm{CO}, \mathrm{NO}_{2}$, NO, $\mathrm{HCN}$ and $\mathrm{CH}_{3} \mathrm{CN}$, Atmos. Chem. Phys., 11, 6445-6463, doi:10.5194/acp-11-6445-2011, 2011.

Singh, H. B., Anderson, B. E., Brune, W. H., Cai, C., Cohen, R. C., Crawford, J. H., Cubison, M. J., Czech, E. P., Emmons, L., Fuelberg, H. E., Huey, G., Jacob, D. J., Jimenez, J. L., Kaduwela, A., Kondo, Y., Mao, J., Olson, J. R., Sachse, G. W., Vay, S. A., Weinheimer, A., Wennberg, P. O., and Wisthaler, A.: Pollution influences on atmospheric composition and chemistry at high north- ern latitudes: Boreal and California forest fire emissions, Atmos. Environ., 44, 4553-4564, doi:10.1016/j.atmosenv.2010.08.026, 2010.

Singh, M., Jaques, P. A., and Sioutas, C.: Size distribution and diurnal characteristics of particle-bound metals in source and receptor sites of the Los Angeles Basin, Atmos. Environ., 36, 16751689, doi:10.1016/S1352-2310(02)00166-8, 2002.

Stephens, M., Turner, N., and Sandberg, J.: Particle Identification by Laser-Induced Incandescence in a Solid-State Laser Cavity, Appl. Optics, 42, 3726-3736, doi:10.1364/AO.42.003726, 2003.

Strausz, O., Jha, K. N., and Montgomery, D. S.: Chemical composition of gases in Athabasca bitumen and in low-temperature thermolysis of oil sand, asphaltene and maltene, Fuel, 56, 114-120, doi:10.1016/0016-2361(77)90128-4, 1977.

Sun, H., Biedermann, L., and Bond, T. C.: Color of brown carbon: A model for ultraviolet and visible light absorption by organic carbon aerosol, Geophys. Res. Lett., 34, L17813, doi:10.1029/2007GL029797, 2007.

Surratt, J. D., Lewandowski, M., Offenberg, J. H., Jaoui, M., Kleindienst, T. E., Edney, E. O., and Seinfeld, J. H.: Effect of Acidity on Secondary Organic Aerosol Formation from Isoprene, Environ. Sci. Technol., 41, 5363-5369, doi:10.1021/es0704176, 2007.

Virkkula, A.: Correction of the Calibration of the 3-wavelength Particle Soot Absorption Photometer ( $3 \lambda$ PSAP), Aerosol Sci. Tech., 44, 706-712, doi:10.1080/02786826.2010.482110, 2010.

Virkkula, A., Ahlquist, N. C., Covert, D. S., Arnott, W. P., Sheridan, P. J., Quinn, P. K., and Coffman, D. J.: Modification, calibration and a field test of an instrument for measuring light absorption by particles, Aerosol Sci. Tech., 39, 68-83, 2005.

White, W. H., Anderson, J. A., Blumenthal, D. L., Husar, R. B., Gillani, N. V., Husar, J. D., and Wilson, W. E., J.: Formation and Transport of Secondary Air Pollutants: Ozone and Aerosols in the St. Louis Urban Plume, Science, 194, 187-189, 1976.

Yang, M., Howell, S. G., Zhuang, J., and Huebert, B. J.: Attribution of aerosol light absorption to black carbon, brown carbon, and dust in China - interpretations of atmospheric measurements during EAST-AIRE, Atmos. Chem. Phys., 9, 2035-2050, doi:10.5194/acp-9-2035-2009, 2009.

Zhang, H., Worton, D. R., Lewandowski, M., Ortega, J., Rubitschun, C. L., Park, J.-H., Kristensen, K., Campuzano-Jost, P., Day, D. A., Jimenez, J. L., Jaoui, M., Offenberg, J. H., Kleindienst, T. E., Gilman, J., Kuster, W. C., de Gouw, J., Park, C., Schade, G. W., Frossard, A. A., Russell, L., Kaser, L., Jud, W., Hansel, A., Cappellin, L., Karl, T., Glasius, M., Guenther, A., Goldstein, A. H., Seinfeld, J. H., Gold, A., Kamens, R. M., and Surratt, J. D.: Organosulfates as Tracers for Secondary Organic Aerosol (SOA) Formation from 2-Methyl-3-Buten-2-ol (MBO) in the Atmosphere, Environ. Sci. Technol., 46, 94379446, doi:10.1021/es301648z, 2012.

Zhang, L., Gong, S., Padro, J., and Barrie, L.: A size-segregated particle dry deposition scheme for an atmospheric aerosol module, Atmos. Environ., 35, 549-560, doi:10.1016/S13522310(00)00326-5, 2001. 